\title{
Article \\ Effect of Se-Enriched Irrigation Water on the Biomass Production and Elemental Composition of Green Bean, Cabbage, Potato and Tomato
}

\author{
Péter Ragályi ${ }^{1} \oplus$, Tünde Takács ${ }^{1, *}$, Anna Füzy ${ }^{1, *}$, Nikolett Uzinger ${ }^{1}$, Péter Dobosy ${ }^{2}$, Gyula Záray ${ }^{2}$, \\ Nóra Szúcs-Vásárhelyi ${ }^{1}$ and Márk Rékási ${ }^{1}$ \\ 1 Institute for Soil Sciences, Centre for Agricultural Research, Herman O. út 15., H-1022 Budapest, Hungary; \\ ragalyi.peter@atk.hu (P.R.); uzinger.nikolett@atk.hu (N.U.); szucs-vasarhelyi.nora@atk.hu (N.S.-V.); \\ rekasi.mark@atk.hu (M.R.) \\ 2 Institute of Aquatic Ecology, Centre for Ecological Research, Karolina út 29-31, H-1113 Budapest, Hungary; \\ dobosy.peter@ecolres.hu (P.D.); zaray.gyula@ecolres.hu (G.Z.) \\ * Correspondence: takacs.tunde@atk.hu (T.T.); fuzy.anna@atk.hu (A.F.)
}

check for updates

Citation: Ragályi, P.; Takács, T.; Füzy, A.; Uzinger, N.; Dobosy, P.; Záray, G.; Szúcs-Vásárhelyi, N.; Rékási, M. Effect of Se-Enriched Irrigation Water on the Biomass Production and Elemental Composition of Green Bean, Cabbage, Potato and Tomato. Plants 2021, 10, 2086. https: / / doi.org/10.3390/plants10102086

Academic Editor: Michela Schiavon

Received: 13 September 2021 Accepted: 29 September 2021 Published: 1 October 2021

Publisher's Note: MDPI stays neutral with regard to jurisdictional claims in published maps and institutional affiliations.

Copyright: (c) 2021 by the authors. Licensee MDPI, Basel, Switzerland. This article is an open access article distributed under the terms and conditions of the Creative Commons Attribution (CC BY) license (https:// creativecommons.org/licenses/by/ $4.0 /)$.

\begin{abstract}
Additional Selenium (Se) intake may be recommended in areas of Se deficiency to prevent various human diseases. One possibility for this is biofortification. In this experiment, the effect of irrigation water containing 100 and $500 \mu \mathrm{g} \mathrm{L}^{-1} \mathrm{Se}$, in the form of $\mathrm{Na}_{2} \mathrm{SeO}_{4}$, on green bean, cabbage, potato and tomato was investigated in a greenhouse pot experiment with sand, silty sand and silt soils. The chlorophyll content index was usually improved by Se and was significantly higher in potato in sand and silty sand and in tomato in silty sand and silt soils. The Se content of edible plant parts increased 63-fold in the $100 \mu \mathrm{g} \mathrm{L}^{-1}$ Se treatment and almost 400 -fold in the $500 \mu \mathrm{g} \mathrm{L}^{-1} \mathrm{Se}$ treatment, averaged over the four species and the three soils. Irrigation water with a Se content of $100 \mu \mathrm{g} \mathrm{L}^{-1}$ may be suitable for the production of functional food in the case of green beans, potatoes and tomatoes. However, due to its greater Se accumulation, cabbage should only be irrigated with a lower Se concentration. The use of Se-enriched irrigation water might be a suitable method for Se biofortification without a significant reduction in plant biomass production and without a remarkable modification of other macro- and microelement contents.
\end{abstract}

Keywords: irrigation; biofortification; selenium; recommended dietary allowance; element content

\section{Introduction}

The selenium (Se) content of soils varies greatly worldwide, from very low to toxic levels even within the same country [1,2]. Its total concentration in the soil is relatively low, generally between 0.01 and $2 \mathrm{mg} \mathrm{kg}^{-1}$ [3], with a global average of $0.4 \mathrm{mg} \mathrm{kg}^{-1}$ [4].

However, in addition to the total Se content of the soil, the availability of Se to plants is also an important aspect which is greatly influenced by the chemical form of the element.

The presence and distribution of different Se forms in soil is a function of the interaction between soil factors. The more mobile selenate $\left(\mathrm{Se}^{6+}\right)$ occurs primarily in alkaline and well-aerated soils, whereas selenite $\left(\mathrm{Se}^{4+}\right)$ is less mobile and more common in neutral or acidic soils and under less oxic conditions. Selenide $\left(\mathrm{Se}^{2-}\right)$ is relatively immobile, is formed under acidic conditions and is strongly bound to mineral or organic compounds. Under reducing conditions, selenium forms may also undergo precipitation [5]. The solubility and plant availability of Se increase with increasing soil pH [6,7]. Selenite sorption correlates well with the Fe and Al contents, so Fe oxides may also play a significant role as Se sorption sites [8]. However, Coppin et al. [9] found that in a grassland soil, Se was bound largely to the organic fraction, with only a minor part bound to mineral components.

The essential role of Se has not been proven for plants, but in certain circumstances, it may have beneficial effects [10], such as mitigating the negative effect of certain abiotic stress factors like heavy metals, drought, salinity and temperature [11-13]. The 
application of Se in certain doses may result in yield increases [14]. A low concentration of supplementary selenium in the growth medium may improve physiological processes, like the efficiency of photosynthesis [12,15-17], especially under abiotic stress conditions. Based on their ability to absorb Se, plant species can be classified as hyperaccumulators (>1000 $\left.\mathrm{mg} \mathrm{kg}^{-1} \mathrm{Se}\right)$, secondary-accumulators (100-1000 $\mathrm{mg} \mathrm{kg}^{-1} \mathrm{Se}$ ) and non-accumulators $\left(<100 \mathrm{mg} \mathrm{kg}^{-1} \mathrm{Se}\right)$ [15].

The Se concentration of the soil in a specific area determines the Se content of wild and cultivated plants and is thus closely related to the daily Se intake of the people and animals living in that area. The ability of plants to absorb Se is essential for human health since Se is known to be an essential nutrient for humans and animals. It plays a significant role as an antioxidant and has diverse effects on health [18]. In areas with a low Se supply, additional Se should be provided [19]. A more direct way to compensate for low Se intake in humans is to produce Se-enriched functional foods, a process known as biofortification [20]. In Finland, the low dietary intake of Se was improved from the 1980s onwards by mixing Na-selenate $\left(\mathrm{Na}_{2} \mathrm{SeO}_{4}\right)$ with fertilizer [21]. Effective measures have also been taken in the UK to increase the Se content of foods [22]. In Hungary, both the Se supply in soils and the Se concentration in the blood of the population are low, so biofortification with Se should be a priority [23].

The enrichment of irrigation water, i.e., fertigation, is one way of producing functional foods in order to enhance the intake of certain elements [24,25].

The biofortification of various plant species with Se has been extensively studied [20,26-28]. Tomato, potato and cabbage have been given considerable attention in this respect, while less research has been reported about beans, although this is the most important legume crop for direct human consumption [29]. According to the literature, Se has been investigated in roughly equal proportions in hydroponic experiments and in a soil medium (either in the field or in pots). When soil was used as the growth medium, Se was typically applied in one or several doses, either by adding a solution to the soil or in the form of leaf spraying [30]. Selenium fertigation, usually applied to the soil throughout the whole vegetation period, has so far only been investigated to a limited extent for melon, tomato [24,25,31], broccoli and canola [32]. These studies were largely conducted in the San Joaquin Valley, California, where it is the high Se content of the irrigation water that is causing the problem [33].

However, Se fortification may have contradictory effects on the element composition of Se-treated plants. The antagonistic or synergistic effect of Se has been studied primarily in human or animal nutrition, with far less research on plant nutrition. Antagonism has been detected between Se and sulphur [34], Se and mercury [35] and Se and molybdenum [36]. The relationship of Se with arsenic species $[37,38]$ and cadmium $[39,40]$ was also studied and found to be either synergistic or antagonistic.

The interaction between Se and other elements may also depend on whether the studies were performed in soil or in hydroponic cultures. Feng et al. [41] investigated Chinese brake fern (Pteris vittata) in both hydroponic and soil culture. In plants grown in soil, Se suppressed the uptake of most of the elements tested, including magnesium $(\mathrm{Mg})$, potassium $(\mathrm{K})$, phosphorus $(\mathrm{P})$, iron $(\mathrm{Fe})$, copper $(\mathrm{Cu})$ and zinc $(\mathrm{Zn})$. In nutrient solution, the uptake of most essential elements was suppressed at lower levels of Se, but higher Se doses had a synergistic effect and stimulated the uptake of $\mathrm{Ca}, \mathrm{Mg}$ and $\mathrm{K}$. This shows that only the results obtained in soil may be relevant if we want to investigate the expected effect of Se in the field.

To the best of our knowledge, this is the first experiment to use Se-enriched irrigation water for the continuous irrigation of green beans, cabbage, potatoes and tomatoes on three different soil types in order to investigate its effects on biomass production and on the concentration of Se and other elements.

The aim of the experiment was to model the effects of elevated Se levels in the irrigation water and of soil texture on the yield and elemental composition of potato, cabbage, tomato and green bean plants. The recent work of Newman et al. [42] also 
drew attention to the human health implications of examining such data. In addition to the elemental composition, the fitness of the plants was examined by measuring the photosynthetic parameters: chlorophyll content index (CCI) and chlorophyll fluorescence $(\mathrm{Fv} / \mathrm{Fm})$, which are good indicators of the physiological effect of Se treatment. Based on the above, the following hypotheses were investigated:

(H1) Dissolved Se applied with irrigation water can theoretically easily reach the roots and be absorbed by the plant. Nevertheless, the uptake of Se may be influenced by soil factors, so it is important to examine the extent of this effect. For this reason, three field soils differing significantly in $\mathrm{pH}$, clay and organic matter (OM) content were used in the pot experiment so that the effect of different soil properties on the fate of selenium could also be investigated. Selenium was expected to be more mobile and available for the test plants on soil with lower clay and OM contents but with a higher $\mathrm{pH}$. (H2) It was expected that the Se treatment up to $500 \mu \mathrm{g} \mathrm{L}{ }^{-1}$ Se concentration in irrigation water would not have a significant negative effect on plant biomass production but that the Se content of the plant tissues would increase. (H3) Se can be enriched in edible plant parts without a significant negative effect on the concentration of other elements, and the vegetables grown can be used as functional foods.

\section{Results}

\subsection{Soil Elemental Composition}

The original plant-available Se contents of the sand, silty sand and silt soils were $0.009,0.016$ and $0.010 \mathrm{mg} \cdot \mathrm{kg}^{-1}$, respectively (see Materials and Methods), which increased 4-10 times in the Se- 1 treatment $\left(0.053,0.065\right.$ and $\left.0.097 \mathrm{mg} \cdot \mathrm{kg}^{-1}\right)$ and $26-47$ times in the Se2 treatment $\left(0.290 ; 0.419\right.$ and $\left.0.472 \mathrm{mg} \cdot \mathrm{kg}^{-1}\right)$, respectively. The plant-available Se contents in all three soils only showed a significant difference in the Se-2 treatment compared to the control, but a considerable increase could already be observed in the Se-1 treatment.

\subsection{Biomass Production}

The average biomass production and dry matter content of the vegetable crops are shown in Table 1. The Se treatments did not cause any significant changes in the biomass of the plants. However, the fresh weight of green bean, cabbage head, potato tuber and tomato fruit decreased non-significantly by 3.5, 6.4, 6.0 and $19.9 \%$ in Se-1 and by $12.8,11.8$, 8.0 and $8.9 \%$ in Se-2, respectively, compared to the control averaged over the three soils. At the same time, the dry matter content increased significantly in cabbage heads (Se-0: $8.9 \pm 0.9 a$, Se-1: $11.2 \pm 1.7 b$, Se-2: $11.2 \pm 1.5 b)$ and tomato fruit (Se-0: $6.67 \pm 0.65 a$, Se-1: $7.39 \pm 0.85 b$, Se-2: $7.87 \pm 0.69 b$ ) as the Se dose increased (Supplementary Tables S1-S4).

Table 1. Average biomass production ( $g \cdot$ plant $^{-1}$ ) and dry matter content $(\%)$ of the vegetable crops.

\begin{tabular}{ccccc}
\hline Parameter & Green Bean & Cabbage & Potato & Tomato \\
\hline Root dry weight $(\mathrm{g})$ & $2.41 \pm 0.90$ & $2.40 \pm 0.91$ & $2.99 \pm 0.78$ & $3.07 \pm 0.76$ \\
Shoot dry weight $(\mathrm{g})$ & $12.8 \pm 2.7$ & - & $9.51 \pm 1.43$ & $28.8 \pm 5.7$ \\
* Edible part fresh weight $(\mathrm{g})$ & $99.7 \pm 21.5$ & $484 \pm 102$ & $183 \pm 13$ & $295 \pm 87$ \\
Edible part dry weight $(\mathrm{g})$ & $10.5 \pm 2.9$ & $50.4 \pm 12.2$ & $36.0 \pm 3.3$ & $21.3 \pm 5.8$ \\
Edible part dry matter content (\%) & $10.4 \pm 1.1$ & $10.4 \pm 1.7$ & $19.7 \pm 1.6$ & $7.31 \pm 0.87$ \\
\hline
\end{tabular}

* Edible parts: green beans, cabbage heads, potato tubers, tomato fruit.

\subsection{Maximum Quantum Efficiency of PSII (Fv/Fm) and Chlorophyll Content Index (CCI)}

In the case of tomato, potato and green bean, neither the soil texture nor Se treatments caused a significant difference in Fv/Fm (Table 2). The Fv/Fm ratio showed the highest values in cabbage leaves, but these values decreased at the higher Se dose, especially in sand. Changes in CCI due to Se addition depended on both the soil texture and the test plant (Table 2). Compared to the control plants, tomatoes grown in silty sand or silt and potatoes grown in sand or silty sand soil responded with significantly increased CCI values. In the case of green bean, the CCI values decreased in the Se- 1 treatment in sand, but 
neither Se-1 nor Se-2 resulted in any change in silty sand or silt. Se had no detectable effect on the chlorophyll content of cabbage.

Table 2. Photosynthetic parameters: Effects of Se treatment on the chlorophyll fluorescence (Fv/Fm) and chlorophyll content index (CCI) of the test plants.

\begin{tabular}{|c|c|c|c|c|c|c|}
\hline \multirow[t]{2}{*}{ Plant } & \multirow[t]{2}{*}{ Parameter } & \multirow{2}{*}{$\begin{array}{c}\text { Se } \\
\text { Dose }\end{array}$} & \multicolumn{3}{|c|}{ Soil Type } & \multirow[t]{2}{*}{ Mean } \\
\hline & & & Sand & Silty Sand & Silt & \\
\hline \multirow{6}{*}{ Green bean } & \multirow{3}{*}{$\mathrm{Fv} / \mathrm{Fm}$} & Se-0 & $0.735 \pm 0.012 \mathrm{aA}$ & $0.764 \pm 0.033 \mathrm{aA}$ & $0.773 \pm 0.023 \mathrm{aA}$ & $0.758 \pm 0.027 \mathrm{~A}$ \\
\hline & & Se-1 & $0.732 \pm 0.018 \mathrm{aA}$ & $0.794 \pm 0.024 \mathrm{aA}$ & $0.766 \pm 0.049 \mathrm{aA}$ & $0.764 \pm 0.039 \mathrm{~A}$ \\
\hline & & Se-2 & $0.741 \pm 0.048 \mathrm{aA}$ & $0.768 \pm 0.009 \mathrm{aA}$ & $0.722 \pm 0.035 \mathrm{aA}$ & $0.761 \pm 0.033 \mathrm{~A}$ \\
\hline & \multirow{3}{*}{$\mathrm{CCI}$} & Se-0 & $14.2 \pm 2.9 \mathrm{aB}$ & $20.6 \pm 1.5 \mathrm{aA}$ & $19.1 \pm 4.1 \mathrm{aA}$ & $18.0 \pm 3.9 \mathrm{~A}$ \\
\hline & & Se-1 & $12.3 \pm 0.9 \mathrm{aA}$ & $20.4 \pm 1.7 \mathrm{bA}$ & $21.3 \pm 4.1 \mathrm{bA}$ & $18.0 \pm 4.9 \mathrm{~A}$ \\
\hline & & Se-2 & $13.4 \pm 0.9 \mathrm{aB}$ & $21.2 \pm 1.5 \mathrm{bA}$ & $18.1 \pm 2.9 \mathrm{bA}$ & $17.6 \pm 3.8 \mathrm{~A}$ \\
\hline \multirow{6}{*}{ Cabbage } & \multirow{3}{*}{$\mathrm{Fv} / \mathrm{Fm}$} & Se-0 & $0.831 \pm 0.003 \mathrm{aB}$ & $0.826 \pm 0.012 \mathrm{aA}$ & $0.836 \pm 0.002 \mathrm{aA}$ & $0.831 \pm 0.008 \mathrm{~B}$ \\
\hline & & Se-1 & $0.829 \pm 0.005 \mathrm{aB}$ & $0.833 \pm 0.001 \mathrm{aA}$ & $0.837 \pm 0.006 \mathrm{aA}$ & $0.833 \pm 0.005 \mathrm{~B}$ \\
\hline & & Se-2 & $0.805 \pm 0.019 \mathrm{aA}$ & $0.818 \pm 0.005 \mathrm{aA}$ & $0.828 \pm 0.005 \mathrm{aA}$ & $0.817 \pm 0.014 \mathrm{~A}$ \\
\hline & \multirow{3}{*}{$\mathrm{CCI}$} & Se-0 & $20.9 \pm 4.3 \mathrm{aA}$ & $24.4 \pm 7.2 \mathrm{aA}$ & $33.0 \pm 16.4 \mathrm{aA}$ & $26.1 \pm 10.7 \mathrm{~A}$ \\
\hline & & Se-1 & $25.5 \pm 0.9 \mathrm{aA}$ & $35.5 \pm 9.7 \mathrm{aA}$ & $33.7 \pm 5.1 \mathrm{aA}$ & $31.6 \pm 7.2 \mathrm{~A}$ \\
\hline & & Se-2 & $28.5 \pm 10.3 \mathrm{aA}$ & $28.5 \pm 2.9 \mathrm{aA}$ & $33.3 \pm 5.2 \mathrm{aA}$ & $30.1 \pm 6.4 \mathrm{~A}$ \\
\hline \multirow{6}{*}{ Potato } & \multirow{3}{*}{$\mathrm{Fv} / \mathrm{Fm}$} & Se-0 & $0.667 \pm 0.028 \mathrm{aA}$ & $0.734 \pm 0.045 \mathrm{aA}$ & $0.726 \pm 0.046 \mathrm{aA}$ & $0.709 \pm 0.047 \mathrm{~A}$ \\
\hline & & Se-1 & $0.709 \pm 0.044 \mathrm{aA}$ & $0.724 \pm 0.065 \mathrm{aA}$ & $0.726 \pm 0.039 \mathrm{aA}$ & $0.720 \pm 0.045 \mathrm{~A}$ \\
\hline & & Se-2 & $0.706 \pm 0.039 \mathrm{aA}$ & $0.717 \pm 0.004 \mathrm{aA}$ & $0.720 \pm 0.052 \mathrm{aA}$ & $0.714 \pm 0.033 \mathrm{~A}$ \\
\hline & \multirow{3}{*}{ CCI } & Se-0 & $11.1 \pm 1.0 \mathrm{aA}$ & $13.1 \pm 2.2 \mathrm{aA}$ & $19.0 \pm 2.0 \mathrm{aA}$ & $14.4 \pm 3.9 \mathrm{~A}$ \\
\hline & & Se-1 & $13.7 \pm 0.7 \mathrm{bB}$ & $10.7 \pm 0.6 \mathrm{aA}$ & $22.9 \pm 0.9 \mathrm{bA}$ & $15.8 \pm 5.5 \mathrm{AB}$ \\
\hline & & Se-2 & $15.4 \pm 2.7 \mathrm{aB}$ & $13.6 \pm 1.3 \mathrm{aB}$ & $24.1 \pm 3.3 \mathrm{aA}$ & $17.7 \pm 5.3 \mathrm{~B}$ \\
\hline \multirow{6}{*}{ Tomato } & \multirow{3}{*}{$\mathrm{Fv} / \mathrm{Fm}$} & Se-0 & $0.786 \pm 0.009 \mathrm{aA}$ & $0.792 \pm 0.006 \mathrm{aA}$ & $0.771 \pm 0.025 \mathrm{aA}$ & $0.783 \pm 0.017 \mathrm{~A}$ \\
\hline & & Se-1 & $0.784 \pm 0.008 \mathrm{aA}$ & $0.778 \pm 0.016 \mathrm{aA}$ & $0.797 \pm 0.015 \mathrm{aA}$ & $0.786 \pm 0.014 \mathrm{~A}$ \\
\hline & & Se-2 & $0.778 \pm 0.017 \mathrm{aA}$ & $0.796 \pm 0.011 \mathrm{aA}$ & $0.796 \pm 0.006 \mathrm{aA}$ & $0.789 \pm 0.015 \mathrm{~A}$ \\
\hline & \multirow{3}{*}{$\mathrm{CCI}$} & Se-0 & $12.5 \pm 3.1 \mathrm{aA}$ & $10.9 \pm 1.0 \mathrm{aA}$ & $16.0 \pm 8.5 \mathrm{aA}$ & $13.1 \pm 5.1 \mathrm{~A}$ \\
\hline & & Se-1 & $17.5 \pm 4.2 \mathrm{aA}$ & $19.4 \pm 1.7 \mathrm{abB}$ & $30.6 \pm 8.2 \mathrm{bB}$ & $22.4 \pm 7.7 \mathrm{~B}$ \\
\hline & & Se-2 & $18.5 \pm 1.5 \mathrm{aA}$ & $29.8 \pm 1.9 \mathrm{abB}$ & $34.3 \pm 2.9 \mathrm{bB}$ & $27.5 \pm 7.5 \mathrm{~B}$ \\
\hline
\end{tabular}

Means \pm std. dev., lower case indicates significant differences between columns (soil types) and capitals between rows (Se doses) (Tukey $\mathrm{HSD}_{5} \%$ ).

\subsection{Elemental Concentrations of the Edible Parts of Vegetables}

\subsubsection{Se Content}

The relatively low Se concentration of $0.024-0.083 \mathrm{mg} \mathrm{kg}^{-1} \mathrm{DW}$ in green beans on control soils increased 72-202-fold in the Se-1 treatment and 667-1732-fold in the Se-2 treatment, depending on the soil type (Table 3 ). Although the changes were already evident as a result of the Se- 1 treatment, a significant difference compared to the control was only detected when the three soils were averaged, whereas the difference caused by the Se-2 treatment was significant on all three soils. In the Se-2 treatment, the Se concentration was significantly higher for sand than for the other two soil types. The Se content was also the highest in sand in the Se-1 treatment, but the difference was not significant.

In cabbage leaf, the Se content increased by approximately two orders of magnitude in the Se- 1 treatment and by three orders of magnitude in the Se- 2 treatment. The Se concentration was the highest on sand, but the difference was only significant in the Se-2 treatment.

In potato tubers, the Se content increased 11-72-fold in the Se-1 treatment, and 61-396-fold in the Se-2 treatment, but a significant difference was only detected between the control and the Se- 2 treatment. The highest values were obtained in sand, but the differences were not significant. 
Table 3. Se concentrations of the edible parts * of vegetables as a function of Se treatments and soil types, $\mathrm{mg} \cdot \mathrm{kg}{ }^{-1} \mathrm{DW}$.

\begin{tabular}{|c|c|c|c|c|c|}
\hline \multirow[t]{2}{*}{ Plant } & \multirow{2}{*}{$\begin{array}{c}\text { Se } \\
\text { Dose }\end{array}$} & \multicolumn{3}{|c|}{ Soil Type } & \multirow[t]{2}{*}{ Mean } \\
\hline & & Sand & Silty Sand & Silt & \\
\hline \multirow{3}{*}{ Green bean } & Se-0 & $0.083 \pm 0.01 \mathrm{aA}$ & $0.024 \pm 0.007 \mathrm{aA}$ & $0.067 \pm 0.023 \mathrm{aA}$ & $0.058 \pm 0.029 \mathrm{~A}$ \\
\hline & Se-1 & $5.95 \pm 0.78 \mathrm{aA}$ & $4.85 \pm 0.31 \mathrm{aA}$ & $5.48 \pm 0.69 \mathrm{aA}$ & $5.43 \pm 0.72 \mathrm{~B}$ \\
\hline & Se-2 & $55.4 \pm 7.9 \mathrm{bB}$ & $41.7 \pm 2.9 \mathrm{aB}$ & $41.8 \pm 3.0 \mathrm{aB}$ & $46.3 \pm 8.2 \mathrm{C}$ \\
\hline \multirow{3}{*}{ Cabbage } & Se-0 & $0.189 \pm 0.015 \mathrm{aA}$ & $0.167 \pm 0.014 \mathrm{aA}$ & $0.283 \pm 0.012 \mathrm{aA}$ & $0.213 \pm 0.055 \mathrm{~A}$ \\
\hline & Se-1 & $23.2 \pm 0.5 \mathrm{aB}$ & $22.4 \pm 1.1 \mathrm{aB}$ & $16.7 \pm 1.1 \mathrm{aB}$ & $20.8 \pm 3.2 \mathrm{~B}$ \\
\hline & Se-2 & $150 \pm 6 \mathrm{bC}$ & $116 \pm 5 \mathrm{aC}$ & $119 \pm 9 \mathrm{aC}$ & $128 \pm 17 \mathrm{C}$ \\
\hline \multirow{3}{*}{ Potato } & Se-0 & $0.205 \pm 0.012 \mathrm{aA}$ & $0.111 \pm 0.018 \mathrm{aA}$ & $0.027 \pm 0.003 \mathrm{aA}$ & $0.114 \pm 0.078 \mathrm{~A}$ \\
\hline & Se-1 & $2.31 \pm 0.22 \mathrm{aA}$ & $2.27 \pm 0.05 \mathrm{aA}$ & $1.95 \pm 0.03 \mathrm{aA}$ & $2.17 \pm 0.21 \mathrm{~B}$ \\
\hline & Se-2 & $12.6 \pm 2.4 \mathrm{aB}$ & $11.0 \pm 1.4 \mathrm{aB}$ & $10.7 \pm 2.3 \mathrm{aB}$ & $11.4 \pm 2.0 \mathrm{C}$ \\
\hline \multirow{3}{*}{ Tomato } & Se-0 & $0.101 \pm 0.008 \mathrm{aA}$ & $0.126 \pm 0.015 \mathrm{aA}$ & $0.194 \pm 0.001 \mathrm{aA}$ & $0.140 \pm 0.042 \mathrm{~A}$ \\
\hline & Se-1 & $5.06 \pm 0.14 \mathrm{aB}$ & $5.05 \pm 0.25 \mathrm{aB}$ & $4.85 \pm 0.18 \mathrm{aB}$ & $4.99 \pm 0.20 \mathrm{~B}$ \\
\hline & Se-2 & $21.6 \pm 1.4 \mathrm{aC}$ & $23.5 \pm 1.0 \mathrm{bC}$ & $24.8 \pm 0.5 \mathrm{bC}$ & $23.3 \pm 1.7 \mathrm{C}$ \\
\hline
\end{tabular}

Means \pm std. dev., lower case indicates significant differences between columns (soil types) and capitals between rows (Se doses) (Tukey $\left.\mathrm{HSD}_{5 \%}\right)$; * green beans, potato tubers, cabbage leaves, tomato fruit.

The Se-1 treatment resulted in a 24-50-fold difference and Se-2 in a 124-214-fold difference in the Se content of tomato fruit, both of which were significant, as was the difference between the Se- 1 and Se- 2 treatments. The Se content was significantly lower in sand in the Se-2 treatment compared to the other soil types.

\subsubsection{Contents of Other Elements}

The P content in green beans consistently decreased as a result of Se treatment, but it was only significant compared to the control, while no significant difference could be detected between the Se- 1 and Se-2 treatments. In cabbage leaf, the P content was primarily influenced by the soil type and exhibited little response to Se treatment. The P content of potato tubers increased significantly in silty sand but decreased in silt in the Se-1 treatment compared to the control, whereas in tomato fruit, it decreased significantly with increasing Se dose (Figure 1).

The K content showed a significant decrease in green beans in the Se- 1 treatment in silty soil. The Se- 2 doses increased the K content in cabbage leaf in sand and silt, whereas the control $\mathrm{K}$ values were the lowest. The changes in $\mathrm{K}$ content in potato were inconsistent, but it decreased significantly in tomato fruit in all the soils in response to either Se-1 or Se-2 treatment.

The Fe content showed no substantial change in green beans and was primarily influenced by the soil type, whereas in cabbage, it significantly decreased in silty sand in the Se- 2 treatment and increased in sand in the Se- 1 treatment compared to the control. In potato tubers, the Fe content tripled in sandy soil and more or less doubled in silty sand and silty soil as a result of the Se-2 treatment, but it decreased significantly in tomato fruit in all the soils compared to control.

The Mg content showed no substantial change in green beans, but it was significantly higher in cabbage leaf in all the soils as the Se dose increased and in tomato fruit in silty sand and silt soils in the Se-1 treatment. However, a decrease was observed in silt soil in the Se-1 treatment.

The Zn content showed an increasing trend in green beans, cabbage and tomato, but this change was only significant in green beans and cabbage in the lighter textured soils, while in tomato, it was significant in sand and silt soils. In potato tubers, the Zn content was significantly reduced compared to the control in all the soils. 


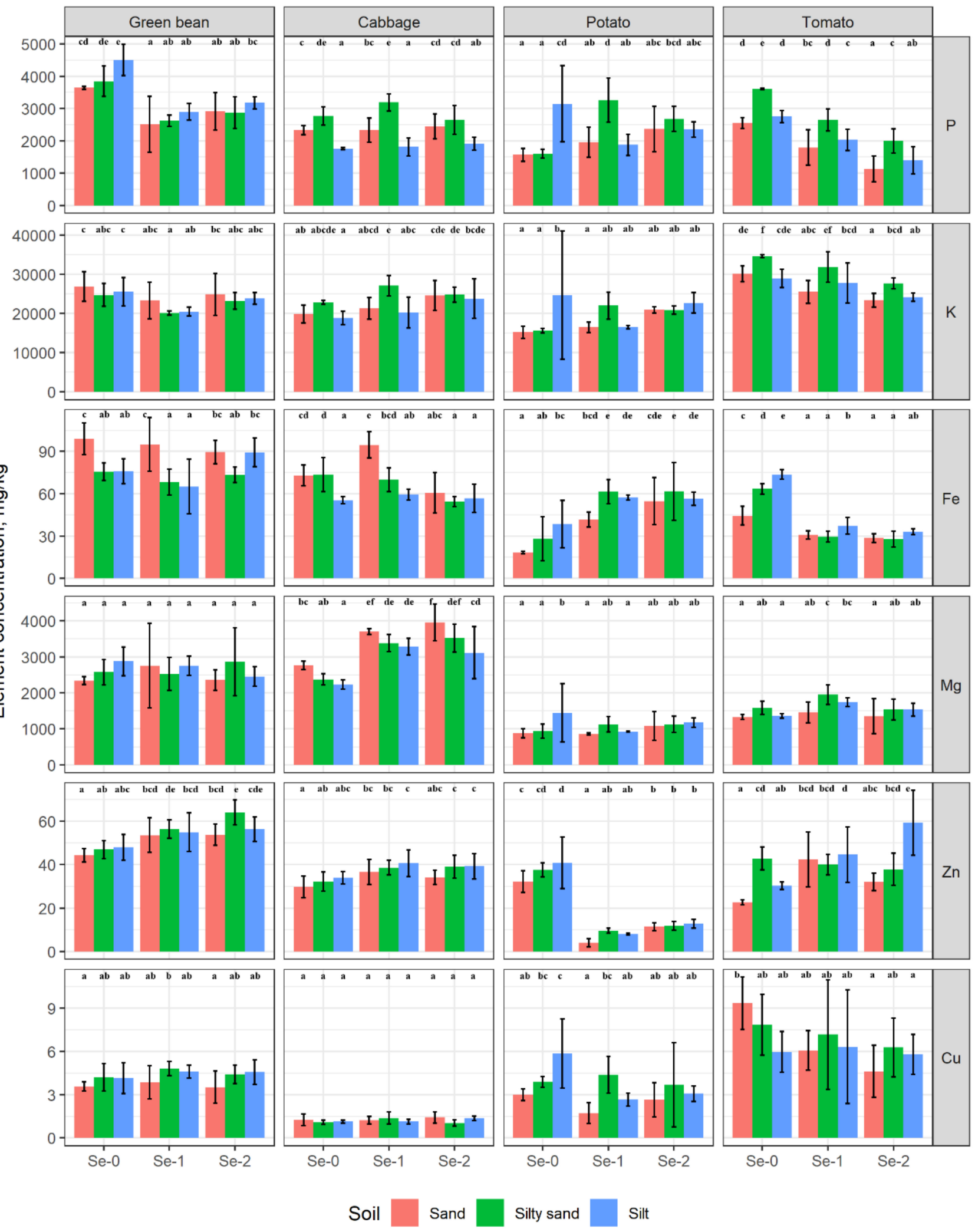

Figure 1. Selected macro- and micro elemental concentrations of the plants, $\mathrm{mg} \cdot \mathrm{kg}^{-1} \mathrm{DW}$. Different letters indicate significant differences between treatments $(p<0.05)$. Error bars represent standard deviations.

The $\mathrm{Cu}$ content was unaffected by Se treatment in either the green beans or the cabbage, but it was significantly reduced in potato compared to the control in all the soils. A decrease was also observed in tomato, which was significant in sandy soil (Figure 1). 
In the plant element content studies, statistically verifiable or trend-like changes were found in the elements described above. The As, B, I, Mn and Ca contents were also analyzed, but they were independent of the treatments, so no detailed description of these has been given. On average the edible parts of green beans, cabbage, potatoes and tomatoes contained 0.010, 0.089, 0.015, $0.007 \mathrm{mg} \mathrm{kg}^{-1}$ As; 17.4, 21.2, 6.61, $12.8 \mathrm{mg} \mathrm{kg}^{-1} \mathrm{~B} ; 0.07,1.15$, $0.829,0.088 \mathrm{mg} \mathrm{kg}^{-1} \mathrm{I}$ and $19.5,28.1,4.85,8.72 \mathrm{mg} \mathrm{kg}^{-1} \mathrm{Mn}$, respectively, in DW.

\subsection{Selenium Content of Edible Parts in Relation with the Recommended and Toxic Selenium Intake}

The Se contents of $100 \mathrm{~g}$ of fresh edible parts of each vegetable are given in Table 4. Cabbage had by far the highest Se content, followed by green beans, potatoes and tomatoes. Averaged over the three soils, the Se-1 treatment caused a 98-fold increase in Se content in beans, a 118-fold increase in cabbage, a 19-fold increase in potatoes and a 39-fold increase in tomatoes compared with the untreated controls, while the Se-2 treatment induced 809, 735, 99 and 195-fold increases, respectively.

Table 4. Se content of edible parts * of vegetables, $\mu \mathrm{g} 100 \mathrm{~g}^{-1}$ in fresh weight.

\begin{tabular}{ccccc}
\hline Plant & Se & \multicolumn{3}{c}{ Soil Type } \\
\cline { 2 - 4 } & Dose & Sand & Silty Sand & Silt \\
\cline { 2 - 4 } Green bean & Se-0 & $0.767 \pm 0.026 \mathrm{aA}$ & $0.263 \pm 0.056 \mathrm{aA}$ & $0.715 \pm 0.270 \mathrm{aA}$ \\
& Se-1 & $55.4 \pm 10.7 \mathrm{aA}$ & $55.9 \pm 3.6 \mathrm{aA}$ & $59.7 \pm 6.5 \mathrm{aA}$ \\
& Se-2 & $493 \pm 64 \mathrm{aB}$ & $454 \pm 51 \mathrm{aB}$ & $465 \pm 50 \mathrm{aB}$ \\
\hline \multirow{3}{*}{ Cabbage } & Se-0 & $1.60 \pm 1.18 \mathrm{aA}$ & $1.37 \pm 0.15 \mathrm{aA}$ & $2.85 \pm 0.23 \mathrm{aA}$ \\
& Se-1 & $252 \pm 22 \mathrm{aA}$ & $222 \pm 41.5 \mathrm{aA}$ & $215 \pm 33 \mathrm{aA}$ \\
& Se-2 & $1551 \pm 261 \mathrm{aB}$ & $1347 \pm 215 \mathrm{aB}$ & $1383 \pm 14 \mathrm{aB}$ \\
\hline \multirow{3}{*}{ Potato } & Se-0 & $4.07 \pm 0.31 \mathrm{aA}$ & $2.12 \pm 0.286 \mathrm{aA}$ & $0.530 \pm 0.030 \mathrm{aA}$ \\
& Se-1 & $46.4 \pm 4.6 \mathrm{aB}$ & $43.1 \pm 2.9 \mathrm{aB}$ & $39.4 \pm 0.7 \mathrm{aB}$ \\
& Se-2 & $230 \pm 19 \mathrm{aC}$ & $226 \pm 16 \mathrm{aC}$ & $209 \pm 15 \mathrm{aC}$ \\
\hline \multirow{3}{*}{ Tomato } & Se-0 & $0.680 \pm 0.086 \mathrm{aA}$ & $0.791 \pm 0.063 \mathrm{aA}$ & $1.36 \pm 0.20 \mathrm{aA}$ \\
& Se-1 & $32.3 \pm 1.5 \mathrm{aB}$ & $40.6 \pm 2.3 \mathrm{aB}$ & $37.5 \pm 2.3 \mathrm{aB}$ \\
& Se-2 & $157 \pm 10 \mathrm{aC}$ & $186 \pm 25 \mathrm{bC}$ & $210 \pm 13 \mathrm{bC}$ \\
\hline
\end{tabular}

Means \pm std. dev., lower case indicates significant differences between columns (soil types) and capitals between rows (Se doses) (Tukey HSD5\%); * see Table 3.

Consuming $100 \mathrm{~g}$ of beans given the Se-1 treatment would cover the daily need for Se, while the same amount of potatoes or tomatoes would provide approximately $70-80 \%$ of the recommended dietary allowance (RDA). In the case of cabbage, however, $100 \mathrm{~g}$ would be equivalent to four times the RDA value. The Se- 2 treatment resulted in Se contents higher than the RDA in all cases, with a 26-fold value for cabbage (Table 5).

Table 6 compares the daily intake with the tolerable upper intake level, which is also known as the hazard quotient (HQ), expressed as a percentage. The amount of Se ingested with $100 \mathrm{~g}$ of fresh vegetables in Se-1-treated foods remained below the tolerable upper intake level (UL) without exception; cabbage approached this level to the greatest extent, with a value of just over $50 \%$. In the Se-2 treatment, on the other hand, green beans reached the UL value and cabbage exceeded it more than 3 times. 
Table 5. Amount of Se ingested with $100 \mathrm{~g}$ of fresh edible vegetable parts * as a percentage of the recommended dietary allowance $(\mathrm{RDA})^{* *}$.

\begin{tabular}{ccccc}
\hline Plant & Se & \multicolumn{3}{c}{ Soil Type } \\
\cline { 2 - 4 } & Dose & Sand & Silty Sand & Silt \\
\hline \multirow{3}{*}{ Green bean } & Se-0 & $1.40 \pm 0.05$ & $0.479 \pm 0.102$ & $1.30 \pm 0.49$ \\
& Se-1 & $101 \pm 20$ & $102 \pm 7$ & $109 \pm 12$ \\
& Se-2 & $897 \pm 116$ & $826 \pm 94$ & $845 \pm 91$ \\
\hline \multirow{3}{*}{ Cabbage } & Se-0 & $2.92 \pm 0.32$ & $2.49 \pm 0.27$ & $5.19 \pm 0.42$ \\
& Se-1 & $458 \pm 41$ & $403 \pm 75$ & $391 \pm 60$ \\
& Se-2 & $2820 \pm 475$ & $2449 \pm 391$ & $2514 \pm 25$ \\
\hline \multirow{3}{*}{ Potato } & Se-0 & $7.40 \pm 0.56$ & $3.85 \pm 0.52$ & $0.963 \pm 0.055$ \\
& Se-1 & $84.3 \pm 8.5$ & $78.3 \pm 5.3$ & $71.7 \pm 1.3$ \\
Tomato & Se-2 & $419 \pm 35$ & $410 \pm 29$ & $381 \pm 27$ \\
& Se-0 & $1.24 \pm 0.16$ & $1.44 \pm 0.12$ & $2.47 \pm 0.37$ \\
& Se-1 & $58.8 \pm 2.8$ & $73.9 \pm 4.1$ & $68.1 \pm 4.1$ \\
& Se-2 & $285 \pm 18$ & $338 \pm 45$ & $381 \pm 24$ \\
\hline
\end{tabular}

* see Table 3; ** Based on $55 \mu \mathrm{g}$ Se RDA in the EU, USA and Canada (Fairweather-Tait et al., 2011).

Table 6. Amount of Se ingested per $100 \mathrm{~g}$ of fresh edible vegetable parts * as a percentage of the tolerable upper intake level (UL) **.

\begin{tabular}{ccccc}
\hline Plant & Se & \multicolumn{3}{c}{ Soil Type } \\
\cline { 2 - 4 } & Dose & Sand & Silty Sand & Silt \\
\cline { 3 - 5 } Green bean & Se-0 & $0.171 \pm 0.006$ & $0.059 \pm 0.012$ & $0.159 \pm 0.060$ \\
& Se-1 & $12.3 \pm 2.4$ & $12.4 \pm 0.8$ & $13.3 \pm 1.4$ \\
& Se-2 & $110 \pm 14$ & $101 \pm 11.4$ & $103 \pm 11$ \\
\hline \multirow{3}{*}{ Cabbage } & Se-0 & $0.356 \pm 0.039$ & $0.304 \pm 0.033$ & $0.634 \pm 0.051$ \\
& Se-1 & $55.9 \pm 5.0$ & $49.2 \pm 9.2$ & $47.8 \pm 7.4$ \\
& Se-2 & $345 \pm 58$ & $299 \pm 48$ & $307 \pm 3$ \\
\hline \multirow{3}{*}{ Potato } & Se-0 & $0.904 \pm 0.069$ & $0.471 \pm 0.063$ & $0.118 \pm 0.007$ \\
& Se-1 & $10.3 \pm 1.0$ & $9.58 \pm 0.65$ & $8.76 \pm 0.16$ \\
Tomato & Se-2 & $51.2 \pm 4.2$ & $50.1 \pm 3.5$ & $46.5 \pm 3.3$ \\
& Se-0 & $0.151 \pm 0.019$ & $0.176 \pm 0.014$ & $0.302 \pm 0.045$ \\
& Se-1 & $7.19 \pm 0.34$ & $9.03 \pm 0.50$ & $8.33 \pm 0.50$ \\
& Se-2 & $34.8 \pm 2.2$ & $41.3 \pm 5.5$ & $46.6 \pm 2.9$ \\
\hline
\end{tabular}

* see Table 3; ** Based on $450 \mu \mathrm{g}$ Se RDA in the EU and UK (Fairweather-Tait et al., 2011).

\section{Discussion}

\subsection{Biomass Production}

Both soil type and Se treatment influenced the biomass production of certain parts of the vegetables in some cases, but no interaction was detected between soil type and Se treatment. In terms of the edible plant parts, i.e., green beans, tomato fruit, potato tubers and cabbage heads, there was a slight decrease in fresh yield as a result of Se treatment, but this effect was not significant.

Although the decrease in green bean biomass was not significant after Se treatment, it was in agreement with the findings of Figueiredo et al. [43], who treated three different varieties of beans (Phaseolus vulgaris) with $5 \mu \mathrm{M} \mathrm{Na}_{2} \mathrm{SeO}_{4}$ in hydroponic culture and observed a decrease in the fresh and dry mature seed weight of two varieties, and an increase in one.

Se treatment may have a growth-promoting effect on cabbage in a hydroponic culture [44]. Zhao et al. [45] treated black cabbage (Brassica campestris) with $2 \mathrm{mg} \mathrm{kg}^{-1}$ Se in a pot experiment involving different $\mathrm{Se}^{6+}-\mathrm{Se} / \mathrm{Se}^{4+}-\mathrm{Se}$ ratios. They found that the yield was reduced as the $\mathrm{Se}^{6+}$-Se content rose to over $0.5 \mathrm{mg} \mathrm{kg}^{-1}$ soil and fell to a quarter at $2.0 \mathrm{mg}$ 
$\mathrm{kg}^{-1}$. In the present experiment, the Se content of the soil remained below $0.5 \mathrm{mg} \mathrm{kg}^{-1}$, and no biomass decrease was observed.

Regarding the effect of Se treatment on the potato yield, the results were similar to those given in the literature. Lei et al. [46] found a negative correlation between increasing Se concentrations in the soil and the fresh weight of red potato tuber. However, as Se stimulated tuber formation, there was a larger number of smaller potatoes. Kádár and Prokisch [47] applied extremely high doses of 90, 270 and $810 \mathrm{~kg} \mathrm{ha}^{-1}$ Se in the form of $\mathrm{Na}_{2} \mathrm{SeO}_{3}$ in a field experiment, resulting in 7,66 and $81 \mathrm{mg} \mathrm{kg}^{-1}$ (resp.) ammonium-acetatelactate soluble Se concentrations in the soil, accompanied by a 16,71 and $88 \%$ loss, respectively, in fresh potato tuber yield. Oliveira et al. [48] also found that above $0.75 \mathrm{mg} / \mathrm{kg}$ Se content in soil, the tuber production of potato showed a significant decrease.

The yield data for tomato fruit showed only minor changes, so the 0.1 and $0.5 \mathrm{mg} \mathrm{Se} \mathrm{L}^{-1}$ doses caused no significant effects; this was also true for root and stem biomass. This was confirmed by Edelstein et al. [24], who found no significant decrease in tomato yield up to a dose of $0.5 \mathrm{mg} \mathrm{Se} \mathrm{L}^{-1}\left(\mathrm{as} \mathrm{Na}_{2} \mathrm{SeO}_{4}\right)$ in the irrigation water in plants grown on perlite. At $1.5 \mathrm{mg} \mathrm{Se} \mathrm{L}^{-1}$, the yield was only $51 \%$ of the control. However, when Foroughbakhch Pournavab et al. [25] used $\mathrm{Na}_{2} \mathrm{SeO}_{3}$ to enrich the irrigation water with 2 or $5 \mathrm{mg} \mathrm{Se} \mathrm{L}{ }^{-1}$, the yield parameters improved for both the stem and fruit of tomato grown in peat-moss or perlite substrate, though the differences were only significant for the stem.

\subsection{Changes in the Chlorophyll Fluorescence Parameter Fv/Fm and the Chlorophyll Content Index (CCI)}

One of the aims of the research was to evaluate the physiological responses of green bean, tomato, cabbage and potato to Se treatments, thus supporting development of the biofortification by optimal Se level in irrigation water. Chlorophyll fluorescence and leaf chlorophyll content are the most widespread, physiology-based indicators of environmental stresses [49]. A low concentration of supplementary selenium in the growth medium may improve the physiological processes of plants [12,15], especially under abiotic stress conditions. The presence of $1 \mu \mathrm{M}$ selenite or selenate ameliorated the photosynthesis of tomato exposed to $\mathrm{Cd}$ contamination [16]. Moreover, $10 \mu \mathrm{M}$ of selenite increased the photosynthesis, stomatal conductance and transpiration of tomato [50]. Diao et al. [51] demonstrated the improved photochemical efficiency of PSII in Se-treated $\left(\mathrm{Na}_{2} \mathrm{SeO}_{3} 0.05 \mathrm{mM}\right)$ tomato. Numerous studies have shown that the application of Se in low concentrations may increase the chlorophyll $(\mathrm{a}+\mathrm{b})$ and carotene content in cabbage leaves [12], maize [52] and faba bean [53]. The present experiment did not confirm the beneficial effect of Se treatment

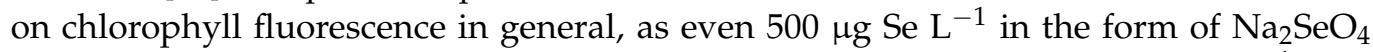
decreased the Fv/Fm of cabbage compared to both the control and the $100 \mu \mathrm{g} \mathrm{Se} \mathrm{\textrm {L } ^ { - 1 }}$ dose (Table 2). The leaf photochemical efficiency ( $\mathrm{Fv} / \mathrm{Fm}$ ) changed within a small range from 0.714 to 0.833 , and its high values indicated a good physiological condition of the test plants. The leaf greenness (measured as CCI value) was a sensitive indicator, not only to Se treatments, but to soil textures and to plant species as well. The highest CCI values in silt soils could be caused by its higher nitrogen supply. As reported by other authors [12], Se addition may significantly increase the CCI chlorophyll level in leaves, except for bean and cabbage.

\subsection{Changes in the Se Concentrations of the Vegetables}

When interpreting changes in elemental contents, it is important to note that they are often influenced by biomass production. As noted above, in most cases Se slightly reduced the biomass, which may have contributed to the higher concentrations of elements, known as the concentration effect [54].

For vegetables, the primary consideration is the Se content of the edible parts. In the present experiment, the $0.02-0.08 \mathrm{mg} \mathrm{kg}^{-1}$ Se concentration in untreated beans (see Table 3 ) was broadly consistent with data from other experiments. The Se content of different varieties of bean seeds increased from around $0.1 \mu \mathrm{g} \mathrm{g}^{-1}$ to $2-4 \mu \mathrm{g} \mathrm{g}^{-1}$ as a result of $5 \mu \mathrm{M}$ $\mathrm{Na}_{2} \mathrm{SeO}_{4}$ treatment [42]. Smrkolj et al. [55] sprayed the leaves of beans with $\mathrm{Na}_{2} \mathrm{SeO}_{4}$ at 


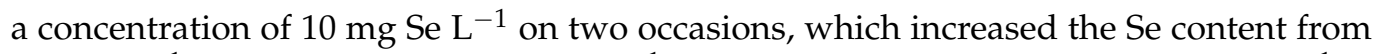
$0.05 \mu \mathrm{g} \mathrm{g}^{-1}$ (DW) of the control to $2 \mu \mathrm{g} \mathrm{g}^{-1}$. The applied concentration of $100 \mu \mathrm{g} \mathrm{Se} \mathrm{\textrm {L } ^ { - 1 }}$ in irrigation water therefore has a stronger effect. However, Azhar-u-ddin et al. [56] set the Se concentration of soils to 1 and $4 \mathrm{mg} \mathrm{Se} \mathrm{kg}^{-1}$, applied in the form of selenate, which resulted in a bean fruit Se concentration of approximately 10 and $20 \mathrm{mg} \mathrm{kg}^{-1}$, respectively, which exceeds the values obtained in Se-1 treatment but does not reach that of Se-2 treatment.

Cabbage belongs to the Brassicaceae family, which is characterized by the ability to accumulate Se in an organic form [57]. Being a secondary accumulator, cabbage may have a Se contents as high as $100-1000 \mathrm{mg} \mathrm{kg}^{-1} \mathrm{DW}$, whereas bean, potato and tomato are non-accumulators [15]. Funes-Collado et al. [58] also found that among the vegetables studied (cabbage, lettuce, chard and parsley), cabbage had the highest Se content. This is consistent with the trends observed in this experiment, as the concentration of Se in the cabbage head is several times higher than in the other three vegetable plants.

With Se- 1 and Se-2 treatments, 1.07 and $5.35 \mathrm{mg}$ Se per pot were applied, respectively, which increased the Se content of potato from 0.11 to 2.2 and $11.4 \mathrm{mg} \mathrm{kg}^{-1}$, respectively. A larger increase was reported by Turakainen et al. [59], who applied a total of $0.75 \mathrm{mg}$ and $3 \mathrm{mg}$ Se in the form of $\mathrm{Na}_{2} \mathrm{SeO}_{4}$ to pots containing $10 \mathrm{~kg}$ of pure quartz sand, which increased the Se in potato stolon from less than $1 \mathrm{mg} \mathrm{kg}^{-1}$ to about 13 and $40 \mathrm{mg} \mathrm{kg}^{-1}$ (resp.). Kádár and Prokisch [47] examined the effect of 90, 270 and $810 \mathrm{~kg} \mathrm{ha}^{-1}$ Se treatment, which increased the $3.4 \mathrm{mg} \mathrm{kg}^{-1}$ Se content of the control to $46.9,84.0$ and $75.4 \mathrm{mg} \mathrm{kg}^{-1}$, respectively, in potato tubers. According to Öborn et al. [60], the Se content of potato positively correlates with soil $\mathrm{pH}$, the tendency of which can be observable in our experiment (Table 3), although the differences were not significant due to the close $\mathrm{pH}$ values of the investigated soils.

In the present experiment, the $0,0.1$ and $0.5 \mathrm{mg} \mathrm{L}^{-1}$ Se applied in the form of $\mathrm{Na}_{2} \mathrm{SeO}_{4}$ resulted in Se contents of 0.14, 4.99 and $23.3 \mu \mathrm{g} \mathrm{g}^{-1}$ (DW) in tomato fruit (Table 3). However, in the case of the Se content measured at the time of harvest in tomatoes, it must be considered that the Se content may decrease during post-harvest ripening [61]. Pezzarossa et al. [62] found a very similar result when treating hydroponically grown tomatoes with $1 \mathrm{mg} \mathrm{Se} \mathrm{L}{ }^{-1}$ in the form of $\mathrm{Na}_{2} \mathrm{SeO}_{4}$ in the nutrient solution, which increased the fruit Se concentration from 0.1 (control) to $10 \mu \mathrm{g} \mathrm{Se} \mathrm{g}{ }^{-1}$ (DW), equivalent to $0.58 \mu \mathrm{g} \mathrm{g}^{-1}$ Se content in the fresh fruit. Edelstein et al. [24], on the other hand, measured an already high content of $80 \mu \mathrm{g} \mathrm{Se} \mathrm{g}^{-1}$ in control tomato fruit, which increased approximately three times, i.e., to $230 \mu \mathrm{g} \mathrm{Se}{ }^{-1}(\mathrm{DW})$, when irrigation water contained $1.5 \mathrm{mg} \mathrm{L}^{-1}$ selenium as $\mathrm{Na}_{2} \mathrm{SeO}_{4}$.

In summary, the Se content of treated potato tubers was relatively low compared to the other plants, whereas cabbage leaves were more efficient in absorbing selenium from the soil.

The Se content of edible plant parts was generally the highest in sandy soil. This may be because the clay content of the soil binds selenium, making it less available. Ajwa et al. [63] also found that plants absorbed less Se in soils with higher clay content compared to looser soils. Zhao et al. [45], however, found that the available Se content was more closely correlated with the silt content than the clay content, although his results showed that the dominant factor was the $\mathrm{CaCO}_{3}$ content, with a correlation coefficient above 0.8 . In the present experiment, the coarse-textured sandy soil had the highest $\mathrm{CaCO}_{3}$ content, so this may have facilitated the increased Se uptake on this soil.

\subsection{How Does Se Affect Other Elements in Vegetables?}

In the present study, Se treatment was found to have a significant effect on the element composition of the edible parts of the vegetables investigated (Figure 1).

$\mathrm{P}$ content underwent frequent and inconsistent changes. Selenite may suppress $\mathrm{P}$ uptake and transport in plants, as found in the case of rice and Chinese brake fern [41,64], but it may also have no effect [25]. One reason for Se and $\mathrm{P}$ antagonism may be the competition between the $\mathrm{SeO}_{3}{ }^{3-}$ and $\mathrm{PO}_{4}{ }^{3-}$ anions [65]. The interaction depends also on the concentration. The addition of $\mathrm{P}$ to growth media with low Se concentrations increased 
the plant Se content up to a certain concentration and then decreased it, while in the case of a medium with higher Se content, the plant Se content continuously increased with increasing P doses [66]. However, in this present experiment, Se was applied in the form of selenate, which was not reported to affect $P$ uptake, and the conversion of selenate to selenite is also unlikely under the experimental conditions used.

Data in the literature on the relationship between Se treatment and plant K content are contradictory, as also reflected in the present results. When Drahoňovský et al. [67] investigated the effect of foliar Se application on 12 plant species, the changes observed in $\mathrm{K}$ contents were diverse. $\mathrm{K}$ plays a significant role in the regulation of osmotic pressure in the cells. Pazurkiewicz-Kocot et al. [68] assumed that changes in the K content of maize (Zea mays) organs after Se application could be attributed to alterations in cell membrane permeability caused by Se. In contrast to the present results, Zhu et al. [69] observed a slight increase in the $\mathrm{K}$ content of tomato after leaf spraying with $1 \mathrm{mg}$ Na-selenate per plant. Similarly, Foroughbakhch Pournavab et al. [25] found that adding Se to the irrigation water in the form of Na-selenite increased the $\mathrm{K}$ content in tomato fruit, but Edelstein et al. [24] reported that Se had no effect of on the K content of tomato fruit when $1.5 \mathrm{mg} / \mathrm{L}$ Na-selenate solution was used for irrigation. Similarly, Narváez-Ortiz et al. [70] found no K content changes in tomato fruit after applying Se in fertilizer solution or foliar spraying. In these studies, the tomato fruit biomass was not or was negatively affected by Se treatment, while in the present experiment, Se treatments resulted in an increment in fruit biomass, which may have caused the lower $\mathrm{K}$ content (dilution effect). However, in the case of cabbage, the $\mathrm{K}$ content in the leaves increased in parallel with the increase in biomass. No direct data were found in the literature on the effect of Se on the K content of cabbage, but the present results contradicted with the findings of Ulhassan et al. [71], where Se treatment had a negative effect, if any, on $\mathrm{K}$ uptake and translocation in various Brassica napus cultivars. In potato tubers a combination of Se and iodine was reported to increase the $\mathrm{K}$ content [72], but in the present experiment, treatment with Se was not effective in this respect.

In this study, Fe showed a significant increase in potato, but there was no clear tendency in the other plants. The Fe content in the human diet is a global issue. Iron deficiency, the most frequent cause of anemia, affects the population worldwide [73], so the significant increment observed in the Fe content of potato is favorable. To the best of our knowledge, the effect of Se on the potato Fe content has not yet been studied. Although tomatoes belong to the same genus, the direction of Fe content change was the opposite to that in potato. As in the present experiment, Zhu et al. [69] reported a non-significant reduction in the Fe content of tomato fruit after leaf spraying with Na-selenate. However, Schiavon et al. [74] only found a reduced Fe content in the root tissue of hydroponically grown tomato treated with $5 \mu \mathrm{M}$ selenium. The decrease in cabbage Fe content in silty sand was in agreement with the findings of He et al. [75], where $1 \mathrm{mg} / \mathrm{kg}$ Se addition to the soil halved the Fe content of Chinese cabbage (Brassica rapa). These diverse results indicate the need for a deeper exploration of the effect of Se on Fe uptake in light of reports on the key role of Se in plant Fe uptake [15].

Se treatment only had a significant influence on the $\mathrm{Mg}$ content in cabbage, where an increment was observed. In contrast, He et al. [75] found that the Mg content of Chinese cabbage and lettuce (Lactuca sativa) remained unchanged after Se treatment. The inconsistent changes in the $\mathrm{Mg}$ content of tomato fruit in the present experiment are reflected in the literature, where Castillo-Godina et al. [76] detected an increase, Edelstein et al. [24] detected a decrease and Foroughbakhch Pournavab et al. [25] detected no change in the Mg content of tomato after Se treatment. Regarding potato, Wang et al. [77] found no changes in $\mathrm{Mg}$ content after Se fertilization in soil, similar to our results observed in lighter textured soils. According to Newman et al. [42], the diversity of the results could also be traced back to differences in the experimental methods applied.

The biofortification of food plants with $\mathrm{Zn}$ is already an important food industry goal in itself [78], so it is gratifying that Se tended to improve the Zn content of edible plant 
parts, with the exception of potatoes. Since an increase in $\mathrm{P}$ and a concomitant decrease in $\mathrm{Zn}$ content were observed in potato, compared with lower $\mathrm{P}$ and higher $\mathrm{Zn}$ content in green bean, one possible reason for this phenomenon could be antagonism between $\mathrm{P}$ and Zn [79]. Boldrin et al. [64] found that Se treatment decreased the P content but significantly increased the $\mathrm{Zn}$ content in rice. However, in cabbage, the $\mathrm{Zn}$ content increased in parallel with P. He et al. [75] detected a very slight, non-significant decrease in the $\mathrm{Zn}$ content of Chinese cabbage and lettuce plants treated with $1 \mathrm{mg} \mathrm{kg}^{-1}$ Se, but $\mathrm{P}$ was not measured. However, Dai et al. [80] found that spiking soil with Se enhances $\mathrm{Zn}$ accumulation in Chinese cabbage plants.

In some cases, the $\mathrm{Cu}$ content decreased in potato and tomato, which is consistent with the results of other research. Schiavon et al. [74] also found reduced $\mathrm{Cu}$ content in tomato roots as a result of $10 \mu \mathrm{M}$ Se treatment. He et al. [75] found a significant decrease in the $\mathrm{Cu}$ content after Se treatment in Chinese cabbage and lettuce. Similarly, in a study of 12 plant species, Drahoňovský et al. [67] observed that Se treatment significantly modified the $\mathrm{Cu}$ content of the plants in only five species and caused a decrease in four of them.

\subsection{Biofortification and Consumability of Functional Foods}

The recommended dietary allowance (RDA) of Se ranges from 25 to $60 \mu \mathrm{g}$ day ${ }^{-1}$ for adult women and from 30 to $75 \mu \mathrm{g}$ day $^{-1}$ for adult men, depending on countries or regions. The gap between deficient and toxic amounts is relatively small. The tolerable upper intake level of Se is only 350-450 $\mu \mathrm{g}$ day ${ }^{-1}$ [4]. The estimated daily intake in Eastern European countries is $30-40 \mu \mathrm{g}$ Se day ${ }^{-1}$, which is slightly below the recommended intake level [81].

Based on the present results, the consumption of $100 \mathrm{~g}$ of fresh edible plant parts of potato and tomato provides close to the $55 \mu \mathrm{g}$ RDA for Se in the EU, USA and Canada, while in the case of green bean, the RDA level is reached [4]. Thus, fertigation with $100 \mu \mathrm{g} \mathrm{Se} \mathrm{L}{ }^{-1}$, the concentration used in the Se- 1 treatment, could be a satisfactory solution for these vegetables, and functional foods grown with this method would not be harmful to health but would compensate for low Se intake (Table 5). However, even this level of biofortification results in Se values 4-4.5 times greater than RDA in cabbage heads, which is also half of the tolerable upper intake level, so in this case, the concentration of Se in the irrigation water should definitely be below $100 \mu \mathrm{g} \mathrm{L}{ }^{-1}$ (Table 6). It is important to know that heat treatment may cause a loss of Se from food or transform Se speciation [82]. In the case of garlic, the more bioavailable organic Se fractions decreased due to protein denaturalization as a result of boiling, baking, microwaving and frying [83]. In contrast, boiling increased the SeMet concentration and reduced the Se(VI) content of cabbage [84]. The present results confirmed that the $20 \mu \mathrm{g} \mathrm{Se} \mathrm{\textrm {L } ^ { - 1 }}$ upper limit commonly used for irrigation water is safe.

The Se-2 treatment resulted in an undesirable increase in the concentration, so the

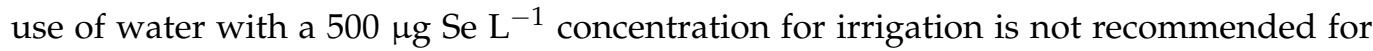
biofortification. It is necessary to note that in addition to the concentration of Se in the irrigation water, the amount of water irrigated, based on the water demand of the plant, determines the amount of total Se applied during the growing season of the plants, which also contributes to the results. Materials and Methods provide information on the total amount of Se applied to each plant in each treatment.

\section{Materials and Methods}

\subsection{Experimental Materials and Conditions}

The effect of Se-enriched irrigation was studied on green bean (Phaseolus vulgaris L., cv. Golden Goal), cabbage (Brassica oleracea L. var. capitata cv. Zora), tomato (Solanum lycopersicum L. cv. Mano) and potato (Solanum tuberosum L. cv. Balatoni rózsa) in an open greenhouse at the Experimental Station of the Center for Agricultural Research in Örbottyán, Hungary [85-87]. A pot experiment was performed using the top 0-20 cm layer of soils from three different locations in Hungary, all having distinct properties: sand (Mollic Umbrisol (Arenic) from Örbottyán), silty sand (Luvic Calcic Phaeozem from 
Gödöllo) and silt (Calcic Chernozem from Hatvan) [88]. The basic characteristics of the air-dry soils are shown in Table 7, and total and mobilizable element concentrations of the soils are shown in Supplementary Table S5.

Table 7. Characteristics of the soils.

\begin{tabular}{|c|c|c|c|}
\hline Characteristic & Sand & Silty Sand & Silt \\
\hline $\mathrm{pH}-\mathrm{H}_{2} \mathrm{O}$ & 7.96 & 6.83 & 7.34 \\
\hline $\mathrm{OM}(\mathrm{w} / \mathrm{w} \%)$ & 0.91 & 1.24 & 2.12 \\
\hline $\mathrm{CaCO}_{3}(\mathrm{w} / \mathrm{w} \%)$ & 1.45 & 0.08 & 0.20 \\
\hline Total N (w/w\%) & 0.064 & 0.092 & 0.135 \\
\hline $\mathrm{NH}_{4}-\mathrm{N}\left(\mathrm{mg} \mathrm{kg}^{-1}\right)$ & 1.4 & 2.3 & 3.9 \\
\hline $\mathrm{NO}_{3}-\mathrm{N}\left(\mathrm{mg} \mathrm{kg}^{-1}\right)$ & 4.7 & 2.3 & 14.2 \\
\hline $\mathrm{AL}-\mathrm{K}_{2} \mathrm{O}\left(\mathrm{mg} \mathrm{kg}^{-1}\right)$ & 74 & 174 & 176 \\
\hline $\mathrm{AL}-\mathrm{P}_{2} \mathrm{O}_{5}\left(\mathrm{mg} \mathrm{kg}^{-1}\right)$ & 131 & 238 & 81 \\
\hline CEC (Na meq/100g) & 9 & 17 & 37 \\
\hline Total Se $\left(\mathrm{mg} \mathrm{kg}^{-1}\right)$ & 0.076 & 0.094 & 0.132 \\
\hline LE Se $\left(\mathrm{mg} \mathrm{kg}^{-1}\right)$ & 0.009 & 0.016 & 0.010 \\
\hline Water soluble Se $\left(\mathrm{mg} \mathrm{kg}^{-1}\right)$ & $<\mathrm{dl}$ & $<\mathrm{dl}$ & $<\mathrm{dl}$ \\
\hline Clay $(<0.002 \mathrm{~mm}, \%)$ & 14 & 23 & 34 \\
\hline Silt (0.002-0.02 mm, \%) & 18 & 30 & 50 \\
\hline Sand $(0.02-2 \mathrm{~mm}, \%)$ & 69 & 46 & 16 \\
\hline
\end{tabular}

AL: ammonium-lactate soluble, Total: aqua regia soluble, LE: ammonium-acetate + EDTA soluble, $<$ dl: under detection limit.

Four holes, each $0.5 \mathrm{~cm}$ in diameter, were drilled in the bottom of the $10 \mathrm{~L}$ pots to allow leached water to escape. The bottom of each pot was filled with gravel with a diameter of $4-8 \mathrm{~mm}$ in a $1 \mathrm{~cm}$ layer, which was covered with a fine synthetic fiber fabric and $10 \mathrm{~kg}$ of soil.

The cabbage and tomato seeds and the potato tubers were first germinated, then planted and grown for three weeks in a commercial growth medium (Vegasca Bio soil mix; Florasca Hungary Ltd.; mixture of peat and grey cattle manure compost. OM $>50 \%$; $\mathrm{N}>0.3 \% ; \mathrm{P}_{2} \mathrm{O}_{5}>0.1 \% ; \mathrm{K}_{2} \mathrm{O}>0.1 \% ; \mathrm{pH}$ of 6.8$)$ under controlled climatic conditions in a growth chamber $\left(16 / 8 \mathrm{~h}\right.$ photoperiod, $25-27 / 15-17^{\circ} \mathrm{C}$ temperature and $600 \mu \mathrm{mol} / \mathrm{m}^{2} / \mathrm{s}$ photon flux density). Soil-free seedlings were transplanted into plastic pots (1 seedling/pot) after a 6-day acclimatization period in the greenhouse. Germinated seeds of green bean were planted directly into the soils ( 1 seed/pot).

The Se-enrichment of the irrigation water started three weeks after planting. The experiment was set up in three replicates on three soil types and included three treatment levels: Se-0: control, Se-1: 100 and Se-2: $500 \mu \mathrm{g} \mathrm{Se} \mathrm{L}{ }^{-1}$ in the form of $\mathrm{Na}_{2} \mathrm{SeO}_{4}$ in the irrigation water. These concentrations are an order of magnitude higher than the recommended values for irrigation water by FAO [89]. The water was stored in $0.5 \mathrm{~m}^{3}$ tanks before the application. Irrigation was carried out with an automatic irrigation system, with individual drip stakes placed in each pot. The daily volume of irrigation water was adjusted according to the requirements of the plants: soil moisture content was monitored at a depth of $10 \mathrm{~cm}$ every hour (Sensor: Decagon EC-5). The nutrient requirements of all the treated plants were met during the vegetation period using $200 \mathrm{~mL}$ Hoagland solution per pot, applied weekly by hand. The total number of plants included in the experiment was 3 Se levels $\times 3$ soil types $\times 4$ plant species $\times 3$ replicates $=108$ plants. Details of the growth period and irrigation are shown in Table 8 .

The plants received natural sunlight in the greenhouse. Climate data were monitored throughout the growth period, as reported in Table 9. Pesticide (Decis, Bayer) was applied whenever necessary. 
Table 8. Growth period and irrigation parameters of the vegetables.

\begin{tabular}{ccccc}
\hline Parameter & Green Bean & Cabbage & Potato & Tomato \\
\hline Growth period & 23 May-24 July & 17 July-25 September & 24 May-17 July & 24 May-21 August \\
Length of growth period (days) & 63 & 71 & 55 & 88 \\
Se solution (mL/pot) & 7750 & 19065 & 10695 & 27125 \\
Se load in $100 \mu \mathrm{g} \mathrm{L}^{-1}$ treatment $(\mathrm{mg} / \mathrm{pot})$ & 0.78 & 1.91 & 1.07 & 2.71 \\
Se load in $500 \mu \mathrm{g} \mathrm{L}^{-1}$ treatment $(\mathrm{mg} / \mathrm{pot})$ & 3.88 & 9.53 & 5.35 & 13.56 \\
\hline
\end{tabular}

Table 9. Greenhouse parameters during the growth period of the vegetables.

\begin{tabular}{ccccc}
\hline Parameter & Green Bean & Cabbage & Potato & Tomato \\
\hline Daytime average temperature $\left({ }^{\circ} \mathrm{C}\right)$ & $25.5 \pm 3.3$ & $25.5 \pm 4$ & $25.6 \pm 3.5$ & $26.6 \pm 3.3$ \\
Nighttime average temperature $\left({ }^{\circ} \mathrm{C}\right)$ & $18.3 \pm 2.3$ & $18.2 \pm 3.4$ & $18.1 \pm 2.3$ & $19.1 \pm 2.3$ \\
Photosynthetically active radiation $\left(\mathrm{W} / \mathrm{m}^{2}\right)$ & $228.7 \pm 106$ & $153.8 \pm 43$ & $240 \pm 107$ & $214.2 \pm 91.6$ \\
Air humidity $(\%)$ & $70.3 \pm 8.6$ & $72.2 \pm 23$ & $69.7 \pm 23.3$ & $69.4 \pm 8.1$ \\
Soil moisture $(\% \mathrm{v} / \mathrm{v})$ & $24 \pm 3$ & $22 \pm 6$ & $22 \pm 6$ & $22 \pm 3$ \\
\hline
\end{tabular}

\subsection{Sample Preparation, Analysis and Measurements}

The plants were washed with deionized water after harvest; then, the plant parts were separated (root, tuber, leafy shoot, fruit), and the fresh biomass was weighed. Subsequently, the roots and aerial parts of the plants were dried at $40{ }^{\circ} \mathrm{C}$ in a laboratory dryer for two days, except for tomato and green bean fruits and potato tubers, which were milled and freeze-dried at $-70{ }^{\circ} \mathrm{C}, 200 \mathrm{~Pa}$ for $72 \mathrm{~h}$, before measuring the dry mass of the plant organs. Dried samples were homogenized with a blending machine, equipped with plastic housing and stainless-steel blade. The dried, homogenized samples were mineralized in a microwave-assisted acid digestion system (TopWave, Analytik Jena, Germany). Plant samples of 400-500 mg were digested in a mixture of $7 \mathrm{~mL} 67 \% \mathrm{HNO}_{3}$ (VWR International, Radnor, PA, USA) and $3 \mathrm{~mL} \mathrm{30 \%} \mathrm{H}_{2} \mathrm{O}_{2}$ (VWR International, PA, USA). After digestion, internal standards (Sc, Y, In) were added to the solutions, which were made up to $15 \mathrm{~mL}$ with deionized water.

The concentrations of selenium, macro- and micro-elements in the dry weight (DW) of plant samples were measured using an inductively coupled plasma mass spectrometer (ICP-MS) (PlasmaQuant Elite, Analytik Jena, Germany).

Composite soil samples were collected from the soils to analyze their basic parameters, and soil samples from each pot were also analyzed after removing the plant residues. The soil samples were dried and sieved through a $2 \mathrm{~mm}$ mesh sieve. The $\mathrm{pH}$ was measured according to the Hungarian Standard Method [90] in a 1:2.5 soil:water suspension $12 \mathrm{~h}$ after mixing, and the OM content was measured using the modified Walkley-Black method [91]. The total $\mathrm{N}$ content was measured with the Kjeldahl method [92], and the $\mathrm{NH}_{4}-\mathrm{N}$ and $\mathrm{NO}_{3}-\mathrm{N}$ concentrations from $\mathrm{KCl}$ extracts were measured according to the Hungarian Standard [93]. The $\mathrm{CaCO}_{3}$ content was measured using the Scheibler gas-volumetric method [90], and the CEC values were measured with the modified method of Mehlich [94]. Plant-available $\mathrm{P}$ and $\mathrm{K}$ concentrations were determined after extraction with ammonium acetate-lactate (AL- $\mathrm{P}_{2} \mathrm{O}_{5}$ and $\mathrm{AL}-\mathrm{K}_{2} \mathrm{O}$ ) [95]. Plant-available Se and other element contents were measured in $0.5 \mathrm{M} \mathrm{NH}_{4}$-acetate $+0.02 \mathrm{M}$ EDTA extract according to Lakanen and Erviö [96] (referred to as LE). The total Se concentrations were determined from the samples using aqua regia in a microwave teflon bomb [97]. The element contents of the soil samples were analyzed using the ICP-MS instrument.

To detect plant physiological responses to Se treatments, the photochemical activity of the photosystem (PS) II (Fv/Fm) of dark adapted leaves (15 min) was measured as the chlorophyll $a$ fluorescence intensity (Opti-Sciences OS-30p+ Fluorometer, Hudson, New Hampshire, USA). $F_{v} / F_{m}$ values were calculated by the method of Tsimilli-Michael and Strasser [98]. The chlorophyll content index (CCI) of the leaves was detected with a Chlorophyll Content Meter (CCM-200 plus, Opti-Sciences, Hudson, NH, USA). The $\mathrm{F}_{\mathrm{v}} / \mathrm{F}_{\mathrm{m}}$ 
and CCI values were measured on the youngest adult leaves at the harvesting stage for all the plants.

\subsection{Statistical Analysis}

A two-factor factorial analysis of variance was used to evaluate the plant parameters, one factor being the soil type and the other the Se dose. The level of significance was set to a $95 \%$ confidence interval $(p<0.05)$. Significantly different groups were determined using Tukey's HSD post hoc test. Statistica v.13 (StatSoft Inc.) software was used for all the statistical calculations. Data visualization was made with $R$ statistical software [99] using a ggplot2 package [100].

\section{Conclusions}

Irrigation water enriched with Se significantly increased the plant-available Se content of the soil, which was lower in sandy soil and higher in silty sand and silt soils. Regarding the Se treatment's effect on plant parameters, our main findings are the following:

The treatments caused a slight decrease in the biomass production of the edible parts of green bean, cabbage, potato and tomato, while the dry matter content of cabbage heads and tomato fruit increased.

Se had a beneficial effect on potato and tomato CCI values, with a significant increase in this parameter in plants.

Se treatment had the greatest effect on the Se content of the edible parts of the plants, which increased by several orders of magnitude, while P, K, Fe, Mg, Zn and Cu increased or decreased depending on the soil types or plant species. Se treatments decreased the $\mathrm{P}$ and $\mathrm{K}$ contents in green beans, the $\mathrm{Zn}$ and $\mathrm{Cu}$ contents in potato and the $\mathrm{P}, \mathrm{K}, \mathrm{Fe}$ and $\mathrm{Cu}$ contents in tomato. Se treatments had a positive effect on $\mathrm{Zn}$ content in green beans; on K, $\mathrm{Mg}$ and $\mathrm{Zn}$ contents in cabbage; on Fe content in potato and on $\mathrm{Zn}$ content in tomato. In the other cases, the changes were different as a function of soil type, or the Se treatment had no effect.

With respect to the soil types, the Se content of the edible plant parts was the highest in sandy soil for most species and treatments.

Based on the Se content of the fresh edible plant parts and the recommended dietary

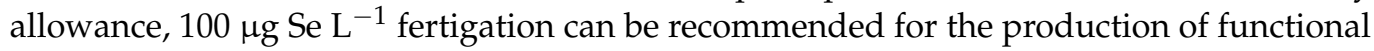
foods for green beans, potatoes and tomatoes, but as cabbage accumulates more Se, irrigation water with a lower Se content is recommended. In the case of cabbage, a more accurate determination of the Se content, and in the case of foods typically consumed after processing, a more detailed examination of the effect of frying and cooking on the Se content could serve as topics for further research. The use of Se-enriched irrigation water might be a suitable method for Se biofortification without a significant reduction in plant biomass production and without a remarkable modification of other macro- and microelement contents.

Supplementary Materials: The following are available online at https:/ /www.mdpi.com/article / 10.3390/plants10102086/s1, Table S1: Effect of Se treatment on the fresh and air-dried biomass production of green bean, g. plant $^{-1}$, Table S2: Effect of Se treatment on the fresh and air-dried biomass production of cabbage, $g$. plant ${ }^{-1}$, Table S3: Effect of Se treatment on the fresh and air-dried biomass production of potato, $\mathrm{g} \cdot$ plant $^{-1}$, Table S4: Effect of Se treatment on the fresh and air-dried biomass production of tomato, g. plant $^{-1}$, Table S5: Total and mobilisable element concentrations in the soils $\left(\mathrm{mg} \cdot \mathrm{kg}^{-1}\right)$.

Author Contributions: P.R. contributed to the implementation of the experiment, prepared the manuscript and conducted the statistical data analyses. T.T. contributed to the implementation of the experiment and carried out the photosynthetic efficiency and chlorophyll content measurements. A.F. conducted the statistical data analyses and proofread the manuscript. N.U. contributed to the data evaluation and proofread the manuscript. P.D. was the leader of the project, performed the analytical experimental work and proofread the manuscript. G.Z. provided substantial contributions to the conception of the study and proofread the manuscript. N.S.-V. contributed to the implementation of 
the experiment. M.R. contributed to the design and implementation of the experiment and proofread the manuscript. All authors have read and agreed to the published version of the manuscript.

Funding: This research was funded by the National Research Development and Innovation Office (grant no. NVKP_16-1-2016-0044) and by the Hungarian Ministry of Agriculture (grant no. AKGF/10/2021_10).

Institutional Review Board Statement: Not applicable.

Informed Consent Statement: Not applicable.

Data Availability Statement: The datasets analyzed during the current study are available from the corresponding author on reasonable request.

Acknowledgments: We are grateful to Ágota Horel for proofreading, corrections and suggestions.

Conflicts of Interest: The authors declare no conflict of interest.

\section{References}

1. Gissel-Nielsen, G.; Gupta, U.C.; Lamand, M.; Westermarck, T. Selenium in soils and plants and its importance in livestock and human nutrition. Adv. Agron. 1984, 37, 397-460. [CrossRef]

2. Long, Z.; Yuan, L.; Hou, Y.; Bañuelos, G.S.; Liu, Y.; Pan, L.; Liu, X.; Yin, X. Spatial variations in soil selenium and residential dietary selenium intake in a selenium-rich county, Shitai, Anhui, China. J. Trace. Elem. Med. Biol. 2018, 50, 111-116. [CrossRef] [PubMed]

3. Mayland, H.F.; James, L.F.; Panter, K.E.; Sonderegger, J.L. Selenium in seleniferous environments. In Selenium in Agriculture and the Environment; Jacobs, L.W., Ed.; SSSA Special Publication no. 23: Madison, WI, USA, 1989; pp. 15-50. [CrossRef]

4. Fairweather-Tait, S.J.; Bao, Y.; Broadley, M.R.; Collings, R.; Ford, D.; Hesketh, J.E.; Hurst, R. Selenium in Human Health and Disease. Antioxid. Redox. Signal 2011, 14, 1337-1383. [CrossRef]

5. Kabata-Pendias, A. Trace Elements in Soils and Plants; CRC Press: Boca Raton, FL, USA, 2010.

6. Xing, K.; Zhou, S.B.; Wu, X.G.; Zhu, Y.Y.; Kong, J.J.; Shao, T.; Tao, X. Concentrations and characteristics of selenium in soil samples from Dashan Region, a selenium-enriched area in China. Soil Sci. Plant Nutr. 2015, 61, 889-897. [CrossRef]

7. Gupta, U.C.; Winter, K.A. Effect of selenate vs. selenite forms of selenium in increasing the selenium concentration in forages and cereals. Can. J. Soil Sci. 1989, 69, 885-888. [CrossRef]

8. Dinh, Q.T.; Li, Z.; Tran, T.A.T.; Wang, D.; Liang, D. Role of organic acids on the bioavailability of selenium in soil: A review. Chemosphere 2017, 184, 618-635. [CrossRef] [PubMed]

9. Coppin, F.; Chabroullet, C.; Martin-Garin, A. Selenite interactions with some particulate organic and mineral fractions isolated from a natural grassland soil. Eur. J. Soil Sci. 2009, 60, 369-376. [CrossRef]

10. White, P.J. Selenium metabolism in plants. BBA-Gen. Subj. 2018, 1862, 2333-2342. [CrossRef]

11. Feng, R.; Wei, C.; Tu, S. The roles of selenium in protecting plants against abiotic stresses. Environ. Exp. Bot. 2013, 87, 58-68. [CrossRef]

12. Hasanuzzaman, M.; Bhuyan, M.H.M.B.; Raza, A.; Hawrylak-Nowak, B.; Matraszek-Gawron, R.; Mahmud, J.A.; Nahar, K.; Fujita, M. Selenium in plants: Boon or bane? Environ. Exp. Bot. 2020, 178, 104170. [CrossRef]

13. Rady, M.M.; Belal, H.E.E.; Gadallah, F.M.; Semida, W.M. Selenium application in two methods promotes drought tolerance in Solanum lycopersicum plant by inducing the antioxidant defense system. Sci. Hortic. 2020, 266, 109290. [CrossRef]

14. Ekanayake, L.J.; Vial, E.; Schatz, B.; McGee, R.; Thavarajah, P. Selenium fertilization on lentil (Lens culinaris Medikus) grain yield, seed selenium concentration, and antioxidant activity. Field Crop Res. 2015, 177, 9-14. [CrossRef]

15. Gupta, M.; Gupta, S. An Overview of Selenium Uptake, Metabolism, and Toxicity in Plants. Front. Plant Sci. 2017, 7, 2074. [CrossRef] [PubMed]

16. Alves, L.R.; Rossatto, D.R.; Rossi, M.L.; Martinelli, A.P.; Gratão, P.L. Selenium improves photosynthesis and induces ultrastructural changes but does not alleviate cadmium-stress damages in tomato plants. Protoplasma 2020, 257, 597-605. [CrossRef] [PubMed]

17. Seppänen, M.; Turakainen, M.; Hartikainen, H. Selenium effects on oxidative stress in potato. Plant Sci. 2003, 165, 311-319. [CrossRef]

18. Rayman, M.P. Selenium and human health. Lancet 2012, 379, 1256-1268. [CrossRef]

19. Gupta, U.C.; MacLeod, J.A. Effect of various sources of selenium fertilization on the selenium concentration of feed crops. Can. J. Soil Sci. 1994, 74, 285-290. [CrossRef]

20. Schiavon, M.; Nardi, S.; Vecchia, F.D.; Ertani, A. Selenium biofortification in the 21st century: Status and challenges for healthy human nutrition. Plant Soil 2020, 453, 245-270. [CrossRef]

21. Hartikainen, H. Biogeochemistry of selenium and its impact on food chain quality and human health. J. Trace Elem. Med. Biol. 2005, 18, 309-318. [CrossRef]

22. Broadley, M.R.; White, P.J.; Bryson, R.J.; Meacham, M.C.; Bowen, H.C.; Johnson, S.E.; Hawkesford, M.J.; McGrath, S.P.; Zhao, F.-J.; Breward, N.; et al. Biofortification of UK food crops with selenium. Proc. Nutr. Soc. 2006, 65, 169-181. [CrossRef] [PubMed] 
23. Gondi, F.; Panto, G.; Feher, J.; Bogye, G.; Alfthan, G. Selenium in Hungary-The rock-soil-human system. Biol. Trace Elem. Res. 1992, 35, 299-306. [CrossRef]

24. Edelstein, M.; Berstein, D.; Shenker, M.; Azaizeh, H.; Ben-Hur, M. Effects of Selenium on Growth Parameters of Tomato and Basil under Fertigation Management. HortScience 2016, 51, 1050-1056. [CrossRef]

25. Foroughbakhch Pournavab, R.; Castillo Godina, R.; Benavides, M.A.; Salas, C.L.R.; Ngangyo, H.M. Agronomic Biofortification with Selenium in Tomato Crops (Solanum lycopersicon L. Mill). Agriculture 2020, 10, 486. [CrossRef]

26. Wiesner-Reinhold, M.; Schreiner, M.; Baldermann, S.; Schwarz, D.; Hanschen, F.S.; Kipp, A.P.; Rowan, D.D.; Bentley-Hewitt, K.L.; McKenzie, M.J. Mechanisms of Selenium Enrichment and Measurement in Brassicaceous Vegetables, and Their Application to Human Health. Front. Plant Sci. 2017, 8, 1365. [CrossRef]

27. Manojlović, M.S.; Lončarić, Z.; Cabilovski, R.R.; Popović, B.; Karalić, K.; Ivezić, V.; Ademi, A.; Singh, B.R. Biofortification of wheat cultivars with selenium. Acta Agric. Scand. B Soil Plant Sci. 2019, 1645204. [CrossRef]

28. Lončarić, Z.; Ivezić, V.; Kerovec, D.; Rebekić, A. Foliar Zinc-Selenium and Nitrogen Fertilization Affects Content of Zn, Fe, Se, P, and $\mathrm{Cd}$ in Wheat Grain. Plants 2021, 10, 1549. [CrossRef]

29. Broughton, W.J.; Hernández, G.; Blair, M.; Beebe, S.; Gepts, P.; Vanderleyden, J. Beans (Phaseolus spp.)-Model food legumes. Plant Soil 2003, 252, 55-128. [CrossRef]

30. Ngigi, P.B.; Lachat, C.; Masinde, P.W.; Du Laing, G. Agronomic biofortification of maize and beans in Kenya through selenium fertilization. Environ. Geochem. Health 2019, 41, 2577-2591. [CrossRef] [PubMed]

31. Grattan, S.R.; Shennan, C.; May, D.M.; Mitchell, J.P.; Burau, R.G. Use of drainage water for irrigation of melons and tomatoes. Calif. Agric. 1987, 41, 27-28.

32. Bañuelos, G.S. Irrigation of Broccoli and Canola with Boron- and Selenium-Laden Effluent. J. Environ. Qual. 2002, 31, 1802-1808. [CrossRef] [PubMed]

33. Albasel, N.; Pratt, P.F.; Westcot, D.W. Guidelines for selenium in irrigation waters. J. Environ. Qual. 1989, 18, 253-258. [CrossRef]

34. Shrift, A. Sulfur-Selenium Antagonism. I. Antimetabolite Action of Selenate on the Growth of Chlorella vulgaris. Am. J. Bot. 1954, 41, 223-230. [CrossRef]

35. Bai, X.; Li, Y.; Liang, X.; Li, H.; Zhao, J.; Li, Y.F.; Gao, Y. Botanic Metallomics of Mercury and Selenium: Current Understanding of Mercury-Selenium Antagonism in Plant with the Traditional and Advanced Technology. Bull. Environ. Contam. Toxicol. 2019, 102, 628-634. [CrossRef] [PubMed]

36. Zhang, M.; Hu, C.; Zhao, X.; Tan, Q.; Sun, X.; Li, N. Impact of molybdenum on Chinese cabbage response to selenium in solution culture. Soil Sci. Plant Nutr. 2012, 58, 595-603. [CrossRef]

37. Sun, H.J.; Rathinasabapathi, B.; Wu, B.; Luo, J.; Pu, L.P.; Ma, L.Q. Arsenic and selenium toxicity and their interactive effects in humans. Environ. Int. 2014, 69, 148-158. [CrossRef]

38. Pokhrel, G.R.; Wang, K.T.; Zhuang, H.M.; Wu, Y.C.; Chen, W.; Lan, Y.; Zhu, X.; Li, Z.; Fu, F.F.; Yang, G.D. Effect of selenium in soil on the toxicity and uptake of arsenic in rice plant. Chemosphere 2020, 239, 124712. [CrossRef]

39. Yang, B.-B.; Yang, C.; Shao, Z.-Y.; Wang, H.; Zan, S.-T.; Zhu, M.; Zhou, S.-B.; Yang, R.-Y. Selenium (Se) Does Not Reduce Cadmium (Cd) Uptake and Translocation in Rice (Oryza sativa L.) in Naturally Occurred Se-Rich Paddy Fields with a High Geological Background of Cd. Bull. Environ. Contam. Toxicol. 2019, 103, 127-132. [CrossRef]

40. Shahid, M.A.; Balal, R.M.; Khan, N.; Zotarelli, L.; Liu, G.D.; Sarkhosh, A.; Fernández-Zapata, J.C.; Nicolás, J.J.M.; Garcia-Sanchez, F. Selenium impedes cadmium and arsenic toxicity in potato by modulating carbohydrate and nitrogen metabolism. Ecotoxicol. Environ. Saf. 2019, 180, 588-599. [CrossRef]

41. Feng, R.; Wei, C.; Tu, S.; Wu, F. Effects of Se on the uptake of essential elements in Pteris vittata L. Plant Soil 2009, 325, 123-132. [CrossRef]

42. Newman, R.; Waterland, N.; Moon, Y.; Tou, J.C. Selenium biofortification of agricultural crops and effects on plant nutrients and bioactive compounds important for human health and disease prevention-A review. Plant Foods Hum. Nutr. 2019, 74, 449-460. [CrossRef]

43. de Figueiredo, M.A.; Boldrin, P.F.; Hart, J.J.; de Andrade, M.J.B.; Guilherme, L.R.G.; Glahn, R.P.; Li, L. Zinc and selenium accumulation and their effect on iron bioavailability in common bean seeds. Plant Physiol. Biochem. 2017, 111, 193-202. [CrossRef]

44. Hajiboland, R.; Amjad, L. The effects of selenate and sulphate supply on the accumulation and volatilization of Se by cabbage, kohlrabi and alfalfa plants grown hydroponically. Agric. Food Sci. 2008, 17, 177-189. [CrossRef]

45. Zhao, C.Y.; Ren, J.H.; Xue, C.Z.; Lin, E.D. Study on the relationship between soil selenium and plant selenium uptake. Plant Soil 2005, 277, 197-206. [CrossRef]

46. Lei, C.; Ma, Q.; Tang, Q.Y.; Ai, X.R.; Zhou, Z.; Yao, L.; Wang, Y.; Wang, Q.; Dong, J.Z. Sodium selenite regulates phenolics accumulation and tuber development of purple potatoes. Sci. Hortic. 2014, 165, 142-147. [CrossRef]

47. Kádár, I.; Prokisch, J. Effect of microelement loads on the yield and element contents of potato on calcareous chernozem soil. Agrokémia Talajt. 2000, 49, 447-464.

48. de Oliveira, V.C.; Faquin, V.; Andrade, F.R.; Carneiro, J.P.; da Silva Júnior, E.C.; de Souza, K.R.D.; Pereira, J.; Guilherme, L.R.G. Physiological and physicochemical responses of potato to selenium biofortification in tropical soil. Potato Res. 2019, 62, 315-331. [CrossRef] 
49. Ahammed, G.J.; Xu, W.; Liu, A.; Chen, S. COMT1 silencing aggravates heat stress-induced reduction in photosynthesis by decreasing chlorophyll content, photosystem II activity, and electron transport efficiency in tomato. Front. Plant Sci. 2018, 9, 998. [CrossRef]

50. Alyemeni, M.N.; Ahanger, M.A.; Wijaya, L.; Alam, P.; Bhardwaj, R.; Ahmad, P. Selenium mitigates cadmium-induced oxidative stress in tomato (Solanum lycopersicum L.) plants by modulating chlorophyll fluorescence, osmolyte accumulation, and antioxidant system. Protoplasma 2018, 255, 459-469. [CrossRef]

51. Diao, M.; Ma, L.; Wang, J.; Cui, J.; Fu, A.; Liu, H.Y. Selenium promotes the growth and photosynthesis of tomato seedlings under salt stress by enhancing chloroplast antioxidant defense system. J. Plant Growth Regul. 2014, 33, 671-682. [CrossRef]

52. Ashraf, M.A.; Akbar, A.; Parveen, A.; Rasheed, R.; Hussain, I.; Iqbal, M. Phenological application of selenium differentially improves growth, oxidative defense and ion homeostasis in maize under salinity stress. Plant Physiol. Biochem. 2018, 123, 268-280. [CrossRef] [PubMed]

53. Mroczek-Zdyrska, M.; Strubińska, J.; Hanaka, A. Selenium improves physiological parameters and alleviates oxidative stress in shoots of lead-exposed Vicia faba L. minor plants grown under phosphorus-deficient conditions. J. Plant Growth Regul. 2017, 36, 186-199. [CrossRef]

54. Jarrell, W.M.; Beverly, R.B. The dilution effect in plant nutrition studies. Adv. Agron. 1981, 34, 197-224. [CrossRef]

55. Smrkolj, P.; Osvald, M.; Osvald, J.; Stibilj, V. Selenium uptake and species distribution in selenium-enriched bean (Phaseolus vulgaris L.) seeds obtained by two different cultivations. Eur. Food Res. Technol. 2007, 225, 233-237. [CrossRef]

56. Huang, J.-C.; Gan, X.; He, S.; Zhou, W. Interactive effects of earthworm Eisenia fetida and bean plant Phaseolus vulgaris L on the fate of soil selenium. Environ. Pollut. 2020, 260, 114048. [CrossRef]

57. Kopsell, D.A.; Randle, W.M. Genetic Variances and Selection Potential for Selenium Accumulation in a Rapid-cycling Brassica oleracea Population. J. Amer. Soc. Hort Sci. 2001, 126, 329-335. [CrossRef]

58. Funes-Collado, V.; Morell-Garcia, A.; Rubio, R.; Lopez-Sanchez, J.F. Selenium uptake by edible plants from enriched peat. Sci. Hortic. 2013, 164, 428-433. [CrossRef]

59. Turakainen, M.; Hartikainen, H.; Sepänen, M. Effect of selenium treatments on potato (Solanum tuberosum L.) growth and concentration of soluble sugars and starch. J. Agric. Food Chem. 2004, 52, 5378-5382. [CrossRef]

60. Öborn, I.; Jansson, G.; Johnsson, L. A field study on the influence of soil ph on trace element levels in spring wheat (Triticum aestivum), potatoes (Solanum tuberosum) and carrots (Daucus carota). Water Air Soil Pollut. 1995, 85, 835-840. [CrossRef]

61. Costa, F.; de Lurdes Baeta, M.; Saraiva, D.; Verissimo, M.T.; Ramos, F. Evolution of Mineral Contents in Tomato Fruits During the Ripening Process After Harvest. Food Anal. Methods 2011, 4, 410-415. [CrossRef]

62. Pezzarossa, B.; Rosellini, I.; Borghesi, E.; Tonutti, P.; Malorgio, F. Effects of Se-enrichment on yield, fruit composition and ripening of tomato (Solanum lycopersicum) plants grown in hydroponics. Sci. Hortic. 2014, 165, 106-110. [CrossRef]

63. Ajwa, H.A.; Bañuelos, G.S.; Mayland, H.F. Selenium uptake by plants from soils amended with inorganic and organic materials. J. Environ. Qual. 1998, 27, 1218-1227. [CrossRef]

64. Boldrin, P.F.; Faquin, V.; Ramos, S.J.; Boldrin, K.V.F.; Avila, F.W.; Guilherme, L.R.G. Soil and foliar application of selenium in rice biofortification. J. Food Compos. Anal. 2013, 31, 238-244. [CrossRef]

65. Li, H.F.; McGrath, S.P.; Zhao, F.J. Selenium uptake, translocation and speciation in wheat supplied with selenate or selenite. New Phytol. 2008, 178, 92-102. [CrossRef] [PubMed]

66. Liu, Q.; Wang, D.; Jiang, X.; Cao, Z.H. Effects of the interactions between selenium and phosphorus on the growth and selenium accumulation in rice (Oryza Sativa). Environ. Geochem. Health 2004, 26, 325-330. [CrossRef]

67. Drahoňovský, J.; Száková, J.; Mestek, O.; Tremlová, J.; Kaňa, A.; Najmanová, J.; Tlustoš, P. Selenium uptake, transformation and inter-element interactions by selected wildlife plant species after foliar selenate application. Environ. Exp. Bot. 2016, 125, 12-19. [CrossRef]

68. Pazurkiewicz-Kocot, K.; Galas, W.; Kita, A. The effect of selenium on the accumulation of some metals in Zea mays L. plants treated with indole-3-acetic-acid. Cell. Mol. Biol. Lett. 2003, 8, 97-103.

69. Zhu, Z.; Zhang, Y.; Liu, J.; Chen, Y.; Zhang, X. Exploring the effects of selenium treatment on the nutritional quality of tomato fruit. Food Chem. 2018, 252, 9-15. [CrossRef]

70. Narváez-Ortiz, W.A.; Becvort-Azcurra, A.A.; Fuentes-Lara, L.O.; Benavides-Mendoza, A.; Valenzuela-García, J.R.; GonzálezFuentes, J.A. Mineral Composition and Antioxidant Status of Tomato with Application of Selenium. Agronomy $2018,8,185$. [CrossRef]

71. Ulhassan, Z.; Gill, R.A.; Ali, S.; Mwamba, T.M.; Ali, B.; Wang, J.; Huang, Q.; Aziz, R.; Zhou, W. Dual behavior of selenium: Insights into physio-biochemical, anatomical and molecular analyses of four Brassica napus cultivars. Chemosphere 2019, 225, 329-341. [CrossRef]

72. Smoleń, S.; Kowalska, I.; Skoczylas, Ł.; Liszka-Skoczylas, M.; Grzanka, M.; Halka, M.; Sady, W. The effect of salicylic acid on biofortification with iodine and selenium and the quality of potato cultivated in the NFT system. Sci. Hortic. 2018, 240, 530-543. [CrossRef]

73. World Health Organization. Worldwide prevalence of anaemia 1993-2005. WHO Global Database on Anaemia. 2008. Available online: http:/ / whqlibdoc.who.int/publications/2008/9789241596657_eng.pdf (accessed on 28 May 2021). 
74. Schiavon, M.; Dall'Acqua, S.; Mietto, A.; Pilon-Smits, E.A.; Sambo, P.; Masi, A.; Malagoli, M. Selenium fertilization alters the chemical composition and antioxidant constituents of tomato (Solanum lycopersicon L.). J. Agric. Food Chem. 2013, 61, 10542-10554. [CrossRef]

75. He, P.P.; Lv, X.Z.; Wang, G.Y. Effects of Se and Zn supplementation on the antagonism against Pb and Cd in vegetables. Environ. Int. 2004, 30, 167-172. [CrossRef]

76. Castillo-Godina, R.G.; Foroughbakhch-Pournavab, R.; Benavides-Mendoza, A. Effect of Selenium on Elemental Concentration and Antioxidant Enzymatic Activity of Tomato Plants. J. Agr. Sci. Tech. 2016, 18, 233-244.

77. Wang, J.W.; Wang, Z.H.; Mao, H.; Zhao, H.B.; Zan, Y.L.; Li, M.H. Effect of Se, Zn and Mo on yield and contents of nutrient elements and selenium and cadmium of potato and cabbage on the Loess Plateau. J. Agro-Environ. Sci. 2012, 31, 2114-2120.

78. Cakmak, I.; Kutman, U.B. Agronomic biofortification of cereals with zinc: A review. Eur. J. Soil Sci. 2018, 69, 172-180. [CrossRef]

79. Cakmak, I.; Marschner, H. Mechanisms of phosphorus-induced zinc deficiency in cotton. I. Zinc deficiency-enhanced uptake rate of phosphorus. Physiol. Plant 1986, 68, 483-490. [CrossRef]

80. Dai, H.P.; Wei, S.H.; Skuza, L.; Jia, G.L. Selenium spiked in soil promoted zinc accumulation of Chinese cabbage and improved its antioxidant system and lipid peroxidation. Ecotox. Environ. Saf. 2019, 180, 179-184. [CrossRef]

81. Rayman, M.P. Food-chain selenium and human health: Emphasis on intake. Br. J. Nutr. 2008, 100, 254-268. [CrossRef]

82. Higgs, D.J.; Morris, V.C.; Levander, O.A. Effect of Cooking on Selenium Content of Foods. J. Agr. Food Chem. 1972, 20, 678-680. [CrossRef] [PubMed]

83. Pérez, M.B.; Maniero, M.Á.; Londonio, A.; Smichowski, P.; Wuilloud, R.G. Effects of common cooking heat treatments on selenium content and speciation in garlic. J. Food Compos. Anal. 2018, 70, 54-62. [CrossRef]

84. Funes-Collado, V.; Rubio, R.; Lopez-Sanchez, J.F. Does boiling affect the bioaccessibility of selenium from cabbage? Food Chem. 2015, 181, 304-309. [CrossRef] [PubMed]

85. Dobosy, P.; Endrédi, A.; Sandil, S.; Vetési, V.; Rékási, M.; Takács, T.; Záray, G.Y. Biofortification of potato and carrot with iodine by applying different soils and irrigation with iodine-containing water. Front. Plant Sci. 2020, 11, 593047. [CrossRef] [PubMed]

86. Dobosy, P.; Vetési, V.; Sandil, S.; Endrédi, A.; Kröpfl, K.; Óvári, M.; Takács, T.; Rékási, M.; Záray, G.Y. Effect of irrigation water containing iodine on plant physiological processes and elemental concentrations of cabbage (Brassica oleracea L. var. capitata L.) and tomato (Solanum lycopersicum L.) cultivated in different soils. Agronomy 2020, 10, 720. [CrossRef]

87. Rékási, M.; Ragályi, P.; Füzy, A.; Uzinger, N.; Dobosy, P.; Záray, G.Y.; Szúcs-Vásárhelyi, N.; Makó, A.; Takács, T. Effect of the boron concentration in irrigation water on the element composition of edible parts of tomato, green bean, potato and cabbage grown on soils with different textures. Front. Plant Sci. 2021, 12, 658892. [CrossRef] [PubMed]

88. IUSS Working Group WRB. World Reference Base for Soil Resources 2014, update 2015. International soil classification system for naming soils and creating legends for soil maps. In World Soil Resources Reports No. 106; FAO: Rome, Italy, 2015.

89. Jeong, H.; Kim, H.; Jang, T. IrrigationWater Quality Standards for Indirect Wastewater Reuse in Agriculture: A Contribution toward Sustainable Wastewater Reuse in South Korea. Water 2016, 8, 169. [CrossRef]

90. MSZ-08-0206/2. Evaluation of some chemical properties of the soil. In Laboratory Tests ( $p H$ Value, Phenolphtalein Alkalinity Expressed in Soda, Total Water Soluble Salt Content, Hydrolytic (y1 Value) and Exchangeable Acidity (y2 Value); Hungarian Standard Association: Budapest, Hungary, 1978.

91. MSZ-08-0452. Use of high-capacity analyser systems for soils analyses. In Quantitative Determination of The Organic Carbon Content of The Soil on Contiflo Analyzer System; Hungarian Standard Association: Budapest, Hungary, 1980.

92. ISO 11261:1995. Soil Quality-Determination of Total Nitrogen-Modified Kjeldahl Method; International Organization for Standardization: Geneva, Switzerland, 1995.

93. MSZ 20135. Determination of The Soluble Nutrient Element Content of The Soil; Hungarian Standard Association: Budapest, Hungary, 1999.

94. MSZ-08-0215. Determination of the cation adsorption capacity of the soil. In Modified Mechlich Technique; Hungarian Standard Association: Budapest, Hungary, 1978.

95. Egnér, H.; Riehm, H.; Domingo, W.R. Untersuchungen über die chemische Bodenan-alyse als Grundlage für die Beurteilung des Nährstoffzustandes der Böden. II. K. Lantbr. Högsk. Ann. 1960, 26, 199-215.

96. Lakanen, E.; Erviö, R. A comparison of eight extractants for the determination of plant available microelements in soils. Acta Agr. Fenn. 1971, 123, 223-232.

97. MSZ 21470-50. Environmental testing of soils. In Determination of Total and Soluble Toxic Element, Heavy Metal and Chromium (VI) Content; Hungarian Standard Association: Budapest, Hungary, 2006.

98. Tsimilli-Michael, M.; Strasser, R.J. In vivo assessment of stress impact on plant's vitality: Applications in detecting and evaluating the beneficial role of mycorrhization on host plants. Mycorrhiza 2008, 3, 679-703. [CrossRef]

99. Core, R.; Team, R. A Language and Environment for Statistical Computing; R Foundation for Statistical Computing: Vienna, Austria, 2020. Available online: https: / / www.R-project.org/ (accessed on 22 June 2021).

100. Wickham, H. ggplot2: Elegant Graphics for Data Analysis; Springer-Verlag: New York, NY, USA, 2016. Available online: https: //ggplot2.tidyverse.org (accessed on 22 June 2021). 